\title{
SEDIMENTARY PETROLOGY AND RESERVOIR QUALITY OF ALBIAN- CENOMANIAN NANUSHUK FORMATION SANDSTONES, USGS WAINWRIGHT \#1 TEST WELL, WESTERN NORTH SLOPE, ALASKA
}

\author{
Kenneth P. Helmold ${ }^{1}$
}

\section{INTRODUCTION}

The U.S. Geological Survey (USGS) conducted a project in 2007 (Clark, 2014) to evaluate the coalbed methane potential of the Albian-Cenomanian Nanushuk Formation as a reliable source of energy for the village of Wainwright, located southwest of Barrow on the Beaufort Sea coast (fig. 3-1). As part of this project the USGS Wainwright \#1 test well was drilled, which included $1,530 \mathrm{ft}$ of continuous core from a depth of 75 to $1,605 \mathrm{ft}$. The analytical program included sampling and measuring the gas content of coals that could have potential as a coalbed methane resource. The sedimentology of the core was documented by LePain and Decker (2016 [this volume]); the regional subsurface context for this core is presented by Decker and LePain (2016 [this volume]). As a parallel study, this report documents the sedimentary petrology and reservoir quality of the Nanushuk siltstones and sandstones encountered in the well.

\section{REGIONAL FRAMEWORK}

The Nanushuk Formation is a thick succession of marine, transitional, and nonmarine strata of Albian to Cenomanian age deposited in the asymmetrical Colville foreland basin (fig. 3-2). The formation is present in outcrop in a belt $30-50 \mathrm{~km}$ wide and roughly $650 \mathrm{~km}$ long in the northern foothills of the Brooks Range. The Nanushuk includes a lower, dominantly marine succession of shale, siltstone, and sandstone deposited in shelf, deltaic, and shoreface settings. The lower unit is gradationally overlain by a dominantly nonmarine succession of mudstone, coal, sandstone, and conglomerate deposited in lower delta plain and alluvial settings (Huffman and others, 1985; LePain and others, 2009; Mull and others, 2003). Together these units form a thick regressive package punctuated by marine transgressions resulting from channel avulsion and subsidence of the abandoned delta lobes (LePain and others, 2009) and episodic pulses of basin subsidence (Molenaar, 1985). The uppermost beds of the Nanushuk consist of a Cenomanian mixed marine, marginal-marine, and nonmarine succession deposited during a regional transgressive episode that culminated in termination of fluvial and deltaic deposition and the re-establishment of widespread marine shelf conditions throughout the central and western North Slope, and deposition of the Turonian Seabee Formation (LePain and others, 2009; Molenaar, 1985).
Early Cretaceous uplift of the Brooks Range resulted in clastic detritus shed into the foreland basin from southern and southwestern terranes. These deposits include the deepwater to nonmarine Fortress Mountain Formation, deepwater turbidites of the Torok Formation, and coeval shallow marine to nonmarine strata of the Nanushuk Formation. The Torok and Nanushuk Formations collectively represent the transition from an underfilled to an overfilled basin (LePain and others, 2009), with Nanushuk strata eventually breaching the Barrow arch in the late Albian (Molenaar, 1985). Regional studies suggest Nanushuk deposition occurred in three large deltaic complexes separated by the north-south-trending Meade arch (Ahlbrandt and others, 1979; Huffman and others, 1985). The Corwin delta is west of the arch and was interpreted to be the product of river-dominated systems (Ahlbrandt and others, 1979; Huffman and others, 1985). It was sourced from a large drainage basin that extended west of present-day Arctic Alaska (Molenaar, 1985). East of the arch, two delta complexes, the Kurupa-Umiat and Grandstand-Marmot deltas, were recognized as river-dominated systems with a greater degree of wave influence (Ahlbrandt and others, 1979; Huffman and others, 1985) and have been reinterpreted as wave-modified to wave-dominated deltas (LePain and others, 2009). They were fed by north-flowing rivers draining smaller catchment areas in the ancestral Brooks Range to the south (Huffman and others, 1985; LePain and others, 2009). Initial work on the petrology of these deltaic systems, with emphasis on mineralogy, reservoir quality, provenance, and petroleum potential, was conducted by Bartsch-Winkler $(1979,1985)$, Bartsch-Winkler and Huffman (1988), and Johnsson and Sokol (2000). Reservoir quality of the Nanushuk sandstones was previously investigated by Reifenstuhl and Loveland (2004). The collective Nanushuk deltaic deposits, along with coeval slope and basinal deposits of the Torok Formations, fill the western portion of the Colville basin (Houseknecht and Schenk, 2001; Houseknecht and others, 2008).

\section{DATASETS}

Fifty-one (51) plugs were cut from the conventional core and submitted to Weatherford Laboratories for routine core analysis. The analyses were run under a net confining stress of $400 \mathrm{psi}$. Because of the rubbly nature of some of the plugs, complete petrophysical data (porosity, permeability, and grain density) could only be obtained for 46 samples (appendices 3-A, 3-B). Trimmed end-cuts 

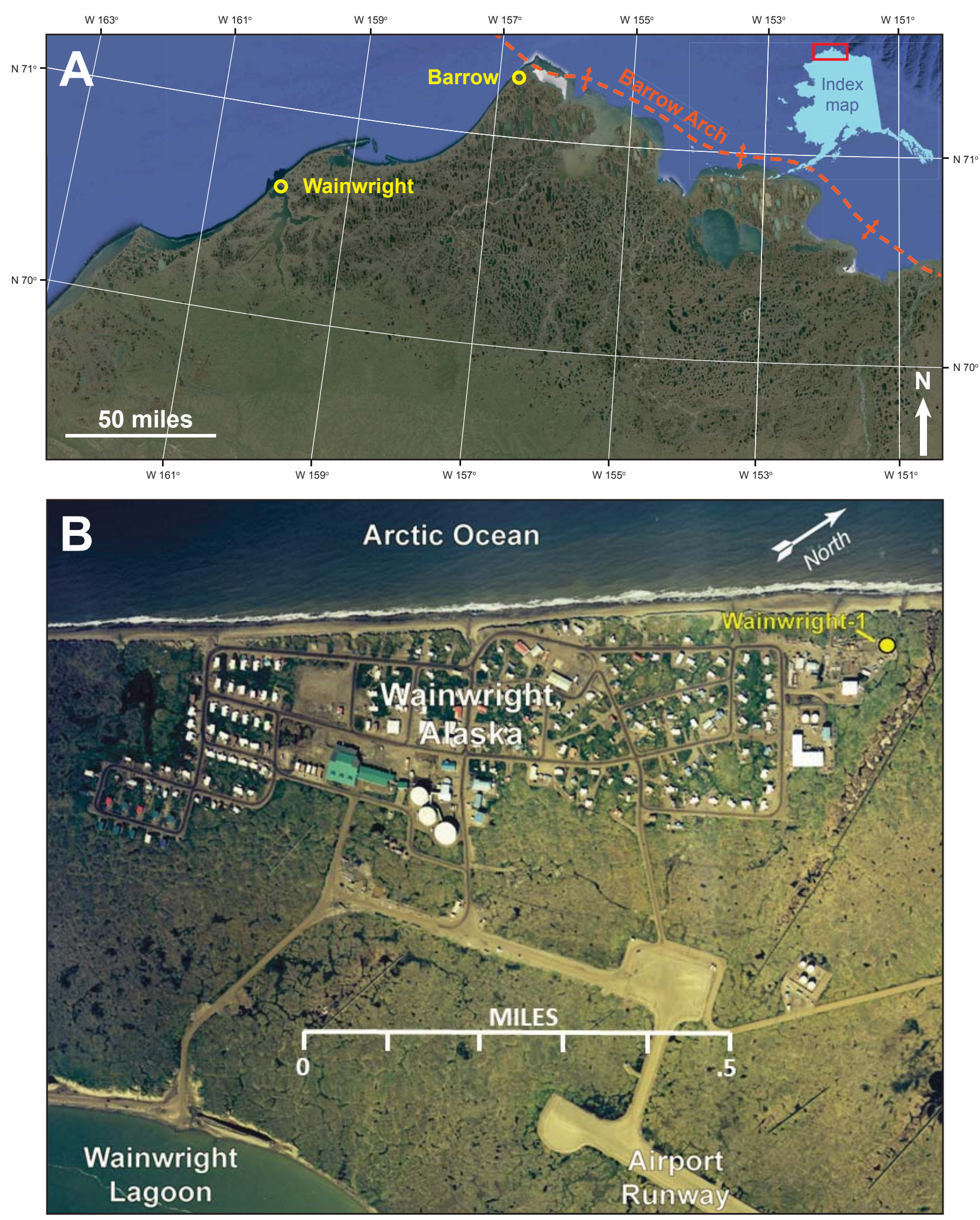

Figure 3-1. A. Google Earth satellite image, showing the location of the villages of Wainwright and Barrow on the North Slope of Alaska. Inset index map of Alaska shows the location of the satellite image. B. Aerial photograph of Wainwright, showing the location of the Wainwright \#1 test well (from Clark, 2014). 
from the plugs were submitted to Petrographics, Inc., of Montrose, CO, for preparation of standard petrographic thin sections. The samples were impregnated with epoxy spiked with both blue and fluorescent dyes prior to thinsection preparation. After initial inspection, 48 sandstones and siltstones were selected for modal analyses, which were performed by Michael D. Wilson of Wilson \& Associates. He counted a minimum of 400 points using the traditional (non Gazzi-Dickinson) point-counting method
(Ingersoll and others, 1984; Decker and Helmold, 1985) to determine the composition of the framework (detrital grains) and intergranular components (matrix, cement, porosity). The modal analyses are presented in two formats: (1) raw counts of Wilson (appendix 3-C), and (2) standardized hierarchical categories originally devised by Decker (1985) and modified by Helmold in subsequent years (appendix 3-D). All interpreted data, plots, and tables in this report are based on the Decker-Helmold

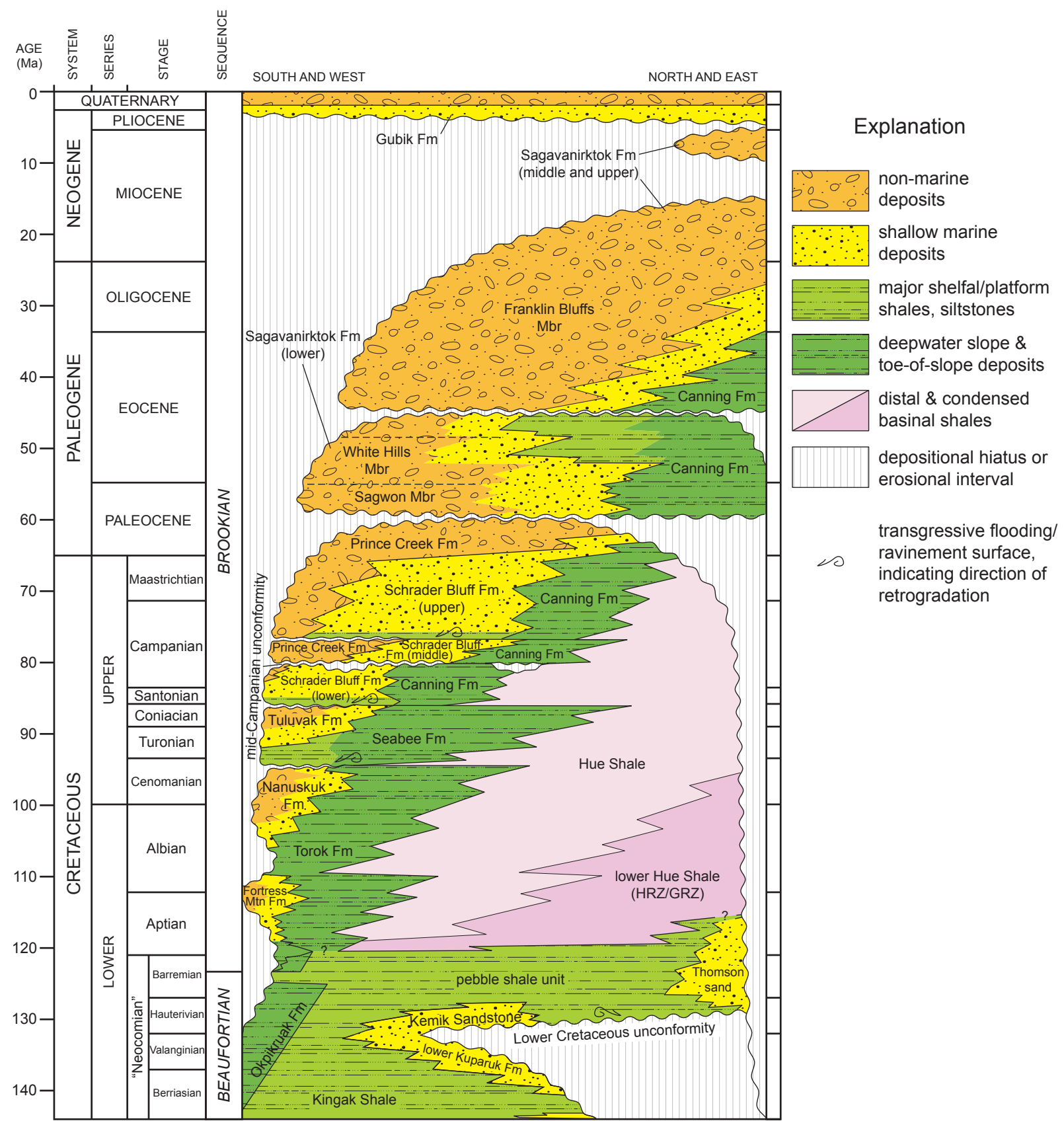

Figure 3-2. Chronostratigraphic column for the Colville basin, Alaska, showing the stratigraphic position of the Nanushuk Formation; revised from Mull and others (2003), Garrity and others (2005), Decker (2010), and Gillis and others (2014). Abbreviations as follows: Fm = Formation; Mbr = Member; Mtn = Mountain; HRZ = Highly radioactive zone; GRZ = Gamma-ray zone. 
system. Summaries of the modal data, standard petrologic parameters, and ternary ratios are presented in appendix 3-E, and petrographic ratios used to construct ternary diagrams are listed in appendix 3-F.

Wilson conducted a second count of 100 grains (including matrix) for each sample for grain size. A complete listing of the grain-size data, in both millimeter and $\varphi$ (phi) units, is presented in appendix 3-G. The original composition and grain-size files provided by Wilson and a file containing the composition data in DeckerHelmold format are available from the DGGS website (doi:10.14509/29657).

\section{PETROLOGIC FACIES}

As part of the detailed core description, LePain and Decker (2016 [this volume]) assigned sedimentologic facies to horizons from which plugs were taken for petrologic and routine core analyses (appendix 3-A, Core Facies). These designations were based largely on sedimentologic characteristics, primarily grain size and sedimentary structures. In several instances the assignments were equivocal because more than one facies was present in close proximity to the sampled horizons. To better integrate the sedimentologic (LePain and Decker, 2016 [this volume]) and petrologic analyses, the thin sections were examined and samples were reassigned to a sedimentary facies based on combined petrologic and sedimentologic criteria (appendix 3-A, TS Facies). The petrology of some of these facies groups were fairly similar, while other facies exhibited significant within-group variability in petrologic parameters. It was therefore decided to analyze the petrology of the samples independent from their sedimentology. The relationship between sedimentary facies and petrofacies is tabulated in table 3-1.

Two samples are heavily carbonate cemented and were assigned to a separate group, which was excluded from further statistical analyses. The remaining samples were grouped into petrofacies using the statistical capabilities of Data Desk, a statistical software application produced by Data Description, Inc. (Velleman, 1998). Fifty-five variables describing petrographic attributes including texture (such as grain size, sorting), composition (such as grain types, matrix, cements), and reservoir quality (such as porosity, permeability, intergranular volume) were amassed into a database. In several cases, mathematical transformations of variables (for example, logarithms of permeability and grain size) were also included. The variables were evaluated to determine suitability for use in allocating samples to petrofacies. Some variables (for example, 'glauconite') contained null values for most of the samples, signifying the absence of glauconite. Other variables (for example, 'quartz cement') contained similar values for most of the samples, resulting in low standard deviations and little discriminating power. The 25 most significant variables were statistically compared with each other to ascertain which pairs had the greatest positive or negative correlation (table 3-2). Three of the most highly correlated variables, representing texture, composition, and reservoir quality, were designated as grouping variables. Grain size (measured in millimeters) was selected to represent texture, bulk chert content to represent composition, and thin-section porosity as a proxy for reservoir quality. Thin-section porosity was chosen over routine (measured) porosity, which was more highly correlated with grain size, so that all three parameters could be ascertained directly from point-count analyses. The three parameters were displayed on a rotating plot in Data Desk (fig. 3-3), which provides an intuitive means to investigate relationships among three variables without using statistical analyses (Velleman, 1998). This fully rotatable plot was studied in all three dimensions to search for clustering of the data into distinct groups. If clusters were apparent, the plot was rotated until maximum separation was obtained among the samples, at which point they were assigned to individual groups (Velleman, 1998). Using this methodology, the samples were assigned to one of four petrofacies; the two cemented samples were allocated to a fifth petrofacies. The petrofacies are designated: (1) Siltstone petrofacies, (2) Very-fine-grained sandstone petrofacies, (3) Fine-grained sandstone petrofacies, (4) Medium-grained sandstone petrofacies, and (5) Carbonate-cemented sandstone petrofacies. The compositions of the petrofacies are illustrated in a series of ternary diagrams (fig. 3-4), their texture is displayed in a plot of cumulative grain size (fig. 3-5), and representative photomicrographs are shown in

Table 3-1. Relationship between sedimentologic facies and petrofacies. Key to sedimentologic facies: SIf = plane-parallel laminated fine-grained sandstone; SIm = plane-parallel laminated medium-grained sandstone; Sx = cross-bedded sandstone; $\mathrm{Sm}=$ massive sandstone; $\mathrm{Sr}=$ ripple cross-laminated sandstone; $\mathrm{Scb}=$ convolute laminated sandstone; SFh = heterolithic sandstone and mudstone; $\mathrm{Fm}=$ massive mudstone.

$\begin{array}{lrrr} & \text { SIf } & \text { SIm } & \text { Sx } \\ \text { Cemented sandstone } & 0 & 0 & 0 \\ \text { Siltstone } & 1 & 0 & 0 \\ \text { Very-fine sandstone } & 9 & 0 & 0 \\ \text { Fine sandstone } & 2 & 12 & 4 \\ \text { Medium sandstone } & 0 & 3 & 0 \\ \text { Total } & \mathbf{1 1} & \mathbf{1 5} & \mathbf{4}\end{array}$

\begin{tabular}{rrrrrr}
\multicolumn{5}{c}{ Sedimentologic Facies } & \\
Sm & Sr & Scb & SFh & Fm & Total \\
1 & 1 & 0 & 0 & 0 & 2 \\
0 & 3 & 3 & 0 & 2 & 9 \\
0 & 5 & 0 & 2 & 0 & 16 \\
3 & 0 & 0 & 0 & 0 & 21 \\
0 & 0 & 0 & 0 & 0 & 3 \\
$\mathbf{3}$ & $\mathbf{1 0}$ & $\mathbf{3}$ & $\mathbf{2}$ & $\mathbf{3}$ & $\mathbf{5 1}$
\end{tabular}




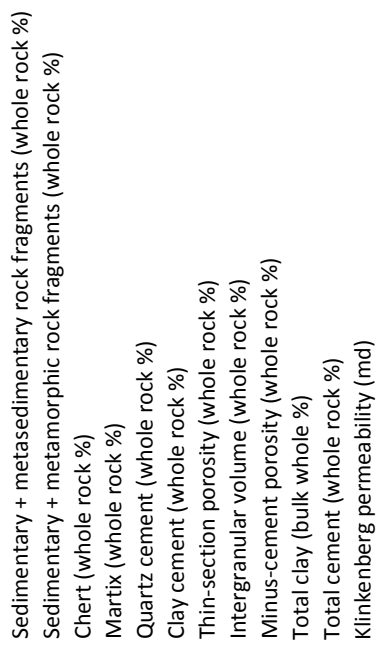

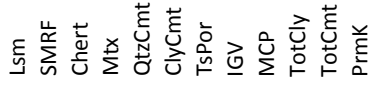

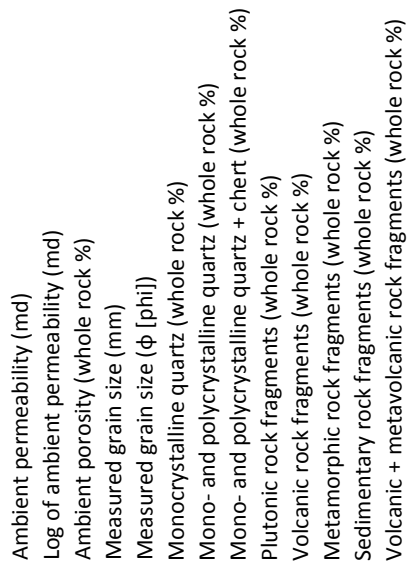

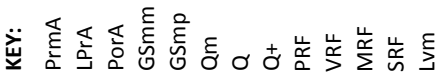


figs. 3-6-3-10. The relationship between the petrofacies and sedimentologic facies of LePain and Decker (2016 [this volume]) are presented in table 3-1.

To assess how these petrofacies compare to other Nanushuk sandstones in terms of composition, texture, and reservoir quality, data from 25 North Slope exploration wells (table 3-3) are included in the various scatter and ternary plots.

\section{SILTSTONE PETROFACIES}

The siltstone petrofacies is represented by nine samples (only six were point-counted) that typically consist of laminated, clay-rich siltstones with a fairly high clay content (fig. 3-6). They have an average modal composition of $\mathrm{Q}_{\mathrm{t71}} \mathrm{F}_{14} \mathrm{~L}_{15}, \mathrm{Q}_{\mathrm{m} 57} \mathrm{~F}_{14} \mathrm{~L}_{\mathrm{t} 29}, \mathrm{Q}_{\mathrm{m} 80} \mathrm{P}_{12} \mathrm{~K}_{8}, \mathrm{Q}_{\mathrm{p} 49} \mathrm{~L}_{\mathrm{vm} 4} \mathrm{~L}_{\mathrm{sm} 46}$ (fig. 3-4, appendix 3-F), and a plagioclase/total feldspar (P/F) ratio of 0.61 . The average grain size (fig. 3-5, appendix 3-G) of the siltstones is $0.011 \mathrm{~mm}$ (fine silt), with an average Folk sorting (Folk, 1974) of 3.39 (very poor). Their framework composition is dramatically different from the sandstones, owing largely to their finer grain size (see section on petrologic trends, below). Monocrystalline quartz $\left(\mathrm{Q}_{\mathrm{m}}\right)$ is the single-most-abundant detrital grain, averaging 48 percent of the framework fraction. Chert is a minor detrital component (4 percent of framework), in contrast to the coarser-grained detritus in which it is more abundant. Feldspar comprises approximately 12 percent of the framework and consists of roughly equal proportions of plagioclase and K-feldspar. Sedimentary rock fragments (SRFs), consisting largely of detrital carbonate, mudstone, and argillite, are the dominant lithic component (average 8 percent of framework), with lesser amounts of felsic volcanic and plutonic grains, phyllite, and quartzite. Micas (average 3.5 percent) and organic material (average 6 percent) are more abundant than in the sandstones, based on their hydrodynamic equivalence with the finer detritus.

Overall reservoir quality of the siltstones is moderately poor to poor with an average air permeability of $1.22 \mathrm{md}$ (0.96 md Klinkenberg permeability) and average porosity of 15 percent (fig. 3-11). They contain significant detrital clay matrix (average 37 percent), which has a pronounced effect on reservoir quality, particularly permeability

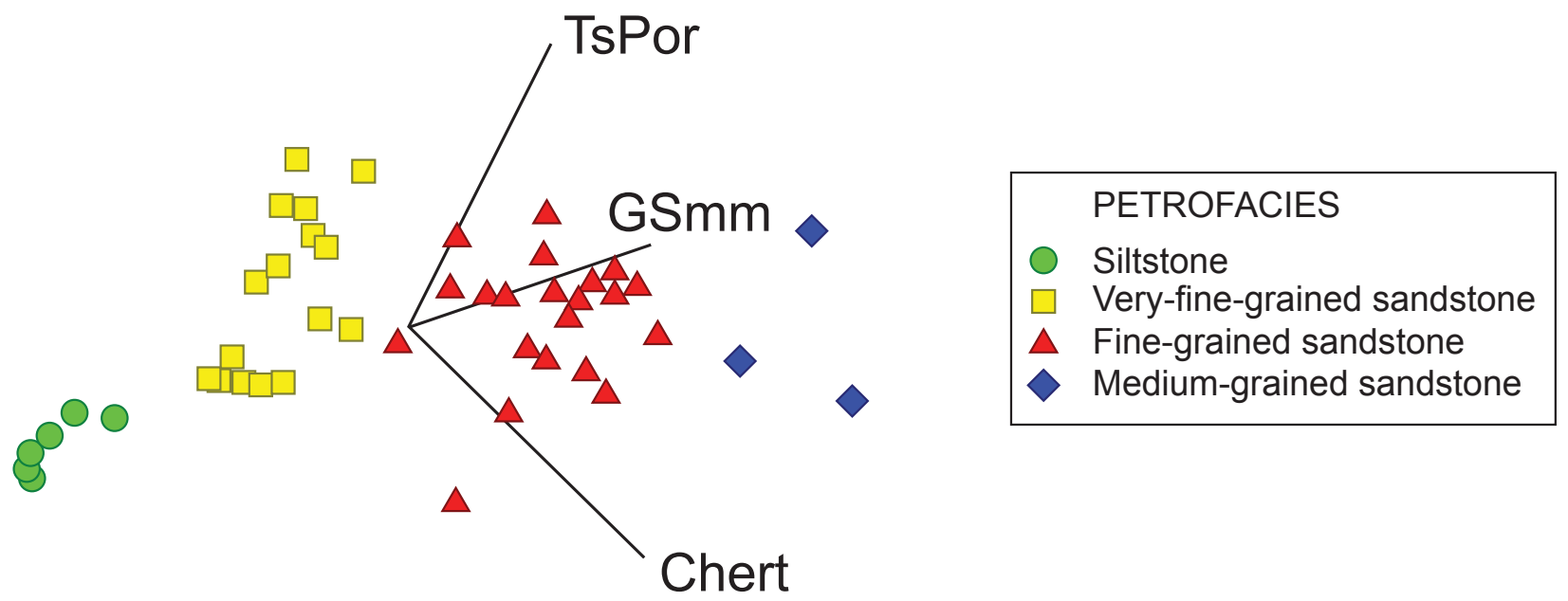

Figure 3-3. Static image of rotating plot used to assign samples to one of four petrofacies. Variables are thin-section porosity (\%), grain size $(\mathrm{mm})$, and chert content (\%). The cemented sandstones are excluded from this plot and assigned to a fifth petrofacies. This plot, which is fully rotatable in the Data Desk environment, provides an intuitive means to investigate relationships among three variables without using statistical analyses. Typically the plot is rotated in all three dimensions until maximum separation is obtained among the samples, at which point they can be assigned to individual groups.

Figure 3-4 (right). Ternary diagrams showing composition of Nanushuk sandstones. The data were obtained via the traditional point-counting method in which phaneritic rock fragments are classified as the appropriate lithology (for example, granite, diorite, gabbro, gneiss). See table 3-4 for explanation of grain and intergranular parameters used in the diagrams. A. $Q_{t} F L$ diagram; most samples plot in the litharenite, feldspathic litharenite, and lithic arkose fields of Folk (1974). Chert is apportioned to the $Q_{t}$ pole, resulting in samples grouping closer to that pole. $\mathbf{B}$. $Q_{m} F L_{t}$ diagram; all samples plot in the litharenite and feldspathic litharenite fields of Folk (1974). Chert is apportioned to the $L_{t}$ pole, resulting in a wide data spread with coarser-grained samples closer to that pole and siltstones closer to the $Q_{m}$ pole. $\mathbf{C}$. $Q_{m} P K$ diagram; the siltstones contain more monocrystalline quartz and therefore plot closer to the $\mathrm{Q}_{m}$ pole. Most samples contain slightly more plagioclase than K-feldspar. D. $Q_{p} L_{v m} L_{s m}$ diagram; all samples plot along the $Q_{p}-L_{s m}$ join, indicating a relative paucity of volcanic and metavolcanic detritus. E. $L_{s} L_{v} L_{m}$ diagram; the lithic population of all samples consists largely of sedimentary rock fragments (SRF). This trend is partially due to the inclusion of chert with the SRFs. F. фCM diagram; the siltstones are enriched in matrix, resulting in poor reservoir quality. The medium- and fine-grained sandstones are most porous; the two cemented sandstones lack any thin-section porosity. 



D
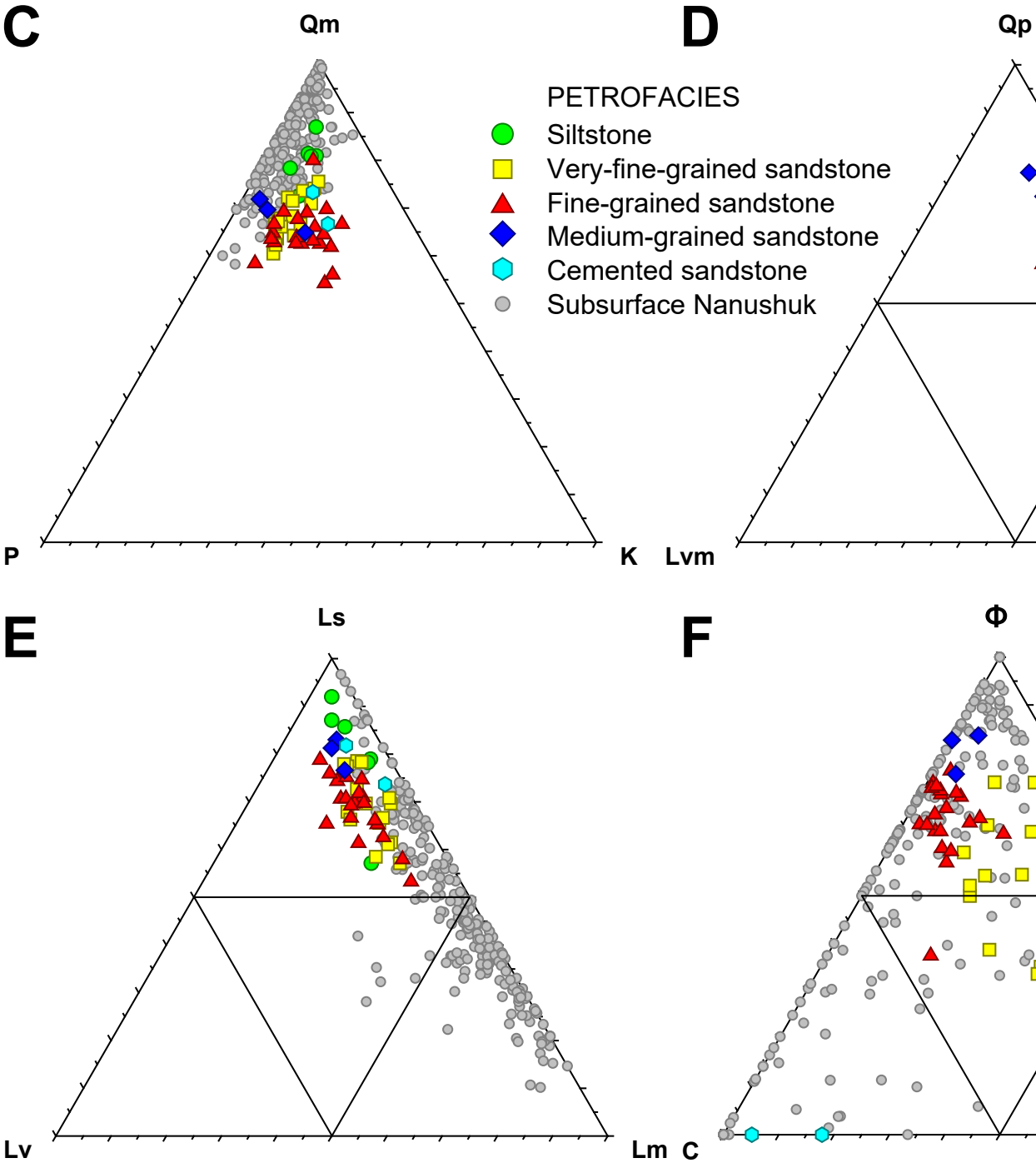

K Lvm

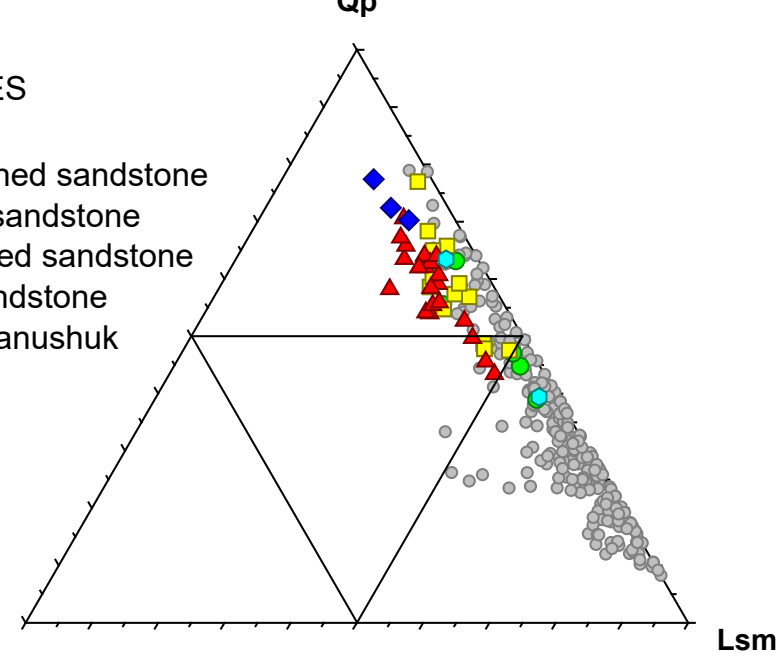

$\mathbf{F}$

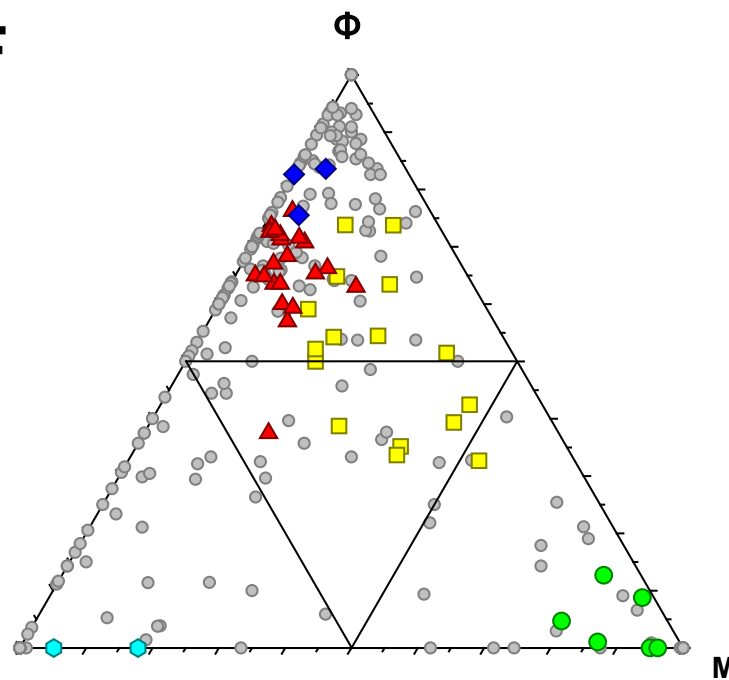


(Neasham, 1977; Howard, 1992). Siderite is a minor cement with a patchy distribution (varies from 0.5 to 6 percent of bulk rock; average 3 percent). The intergranular volume (IGV) is high (average 41 percent), largely due to the abundant matrix.

One sample of this petrofacies belongs to the planeparallel laminated sandstone (Slf) facies, three to the ripple cross-laminated sandstone ( $\mathrm{Sr}$ ) facies, three to the convolute laminated sandstone ( $\mathrm{Scb}$ ) facies, and two to the massive mudstone (Fm) facies (table 3-1).
VERY-FINE-GRAINED SANDSTONE PETROFACIES

The very-fine-grained sandstone petrofacies is represented by 16 feldspathic litharenites and litharenites (figs. 3-4 and 3-7). They have an average modal composition of $\mathrm{Q}_{\mathrm{t} 62} \mathrm{~F}_{16} \mathrm{~L}_{22}, \mathrm{Q}_{\mathrm{m} 35} \mathrm{~F}_{16} \mathrm{~L}_{\mathrm{t} 49}, \mathrm{Q}_{\mathrm{m} 68} \mathrm{P}_{21} \mathrm{~K}_{11}, \mathrm{Q}_{\mathrm{p} 59} \mathrm{~L}_{\mathrm{vm} 6} \mathrm{~L}_{\mathrm{sm} 35}$ (fig. 3-4, appendix 3-F), and a plagioclase/total feldspar (P/F) ratio of 0.66 . Their average grain size (fig. 3-5, appendix $3-\mathrm{G}$ ) is $0.08 \mathrm{~mm}$ (lower very fine), with an average Folk sorting (Folk, 1974) of 1.83 (poor). Monocrystalline $\left(\mathrm{Q}_{\mathrm{m}}\right)$ and polycrystalline $\left(\mathrm{Q}_{\mathrm{p}}\right)$ quartz are the two dominant framework components, averaging 31 and 12 percent of
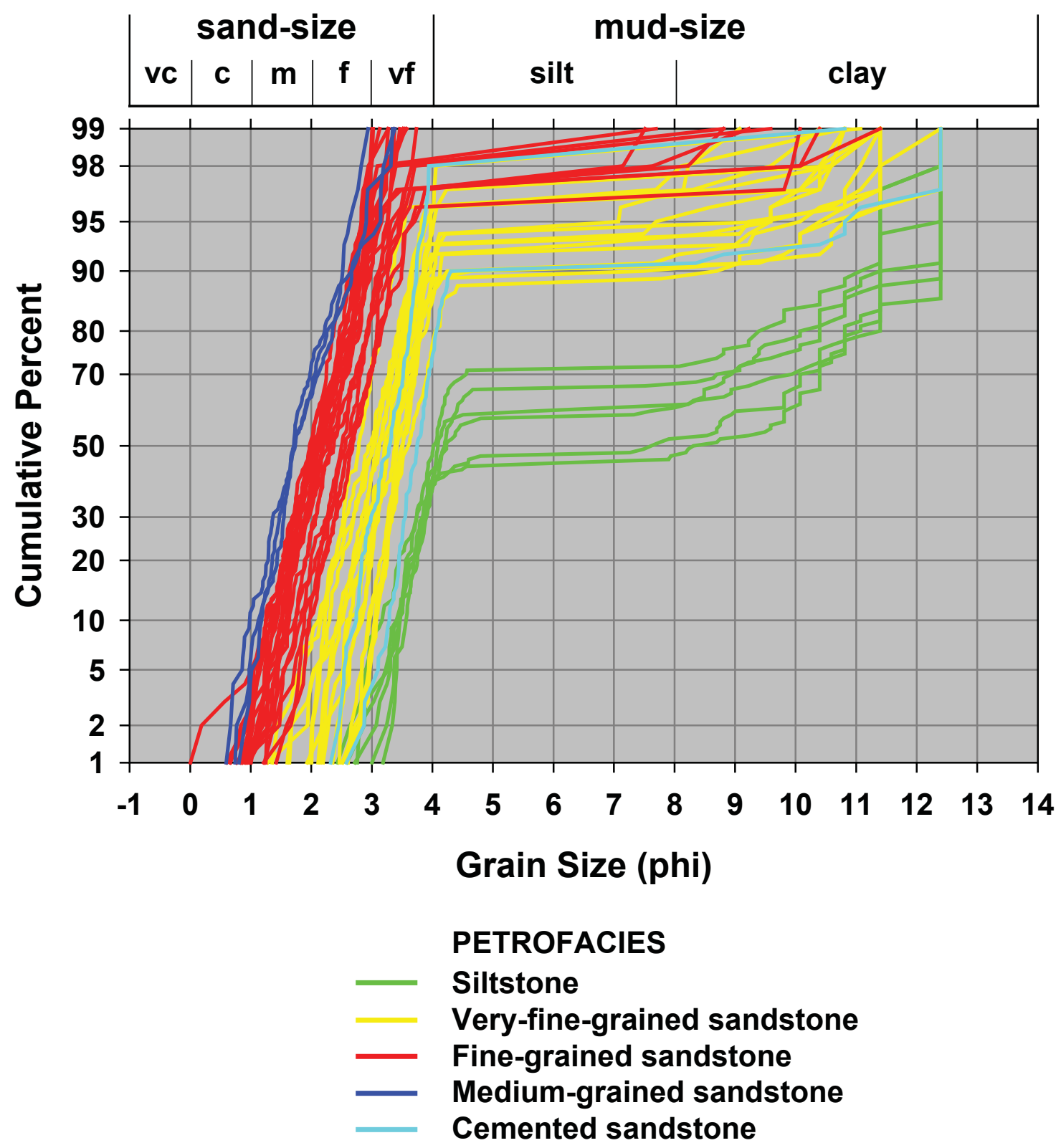

Figure 3-5. Cumulative probability plots of grain size by petrofacies; each line represents a single sample. Samples with a normal (Gaussian) distribution plot as a straight line; right-directed tails indicate abundant matrix (both silt and clay). The value of the 50th percentile indicates median grain size, while the slope of the line indicates sorting. 
Table 3-3. Wells for which data are included in scatter and ternary plots. Erosion estimates are derived from Burns and others, 2005.

\begin{tabular}{|c|c|c|c|c|c|c|c|}
\hline Number & Operator & Well & API & $\begin{array}{c}\text { Top Zone } \\
\text { (feet) }\end{array}$ & $\begin{array}{l}\text { Base Zone } \\
\text { (feet) }\end{array}$ & $\mathbf{N}$ & $\begin{array}{c}\text { Erosion } \\
\text { (feet) }\end{array}$ \\
\hline 1 & U.S. Navy & Barrow Core Test 1 & 50023100050000 & 169.0 & 194.0 & 6 & 2,725 \\
\hline 2 & Arco & Big Bend 1 & 50287200110000 & $1,100.0$ & $2,830.0$ & 9 & 8,002 \\
\hline 3 & Husky & E Simpson 2 & 50279200070000 & $2,387.0$ & $2,398.0$ & 9 & 1,785 \\
\hline 4 & U.S. Navy & Fish Ck 1 & 50103100010000 & $2,970.6$ & $3,032.9$ & 5 & 1,103 \\
\hline 5 & U.S. Navy & Grandstand 1 & 50057100010000 & 227.5 & $1,068.0$ & 22 & 8,084 \\
\hline 6 & Arco & Hunter A & 50103204050000 & $3,625.0$ & $3,652.0$ & 7 & 2,068 \\
\hline 7 & Husky & Inigok 1 & 50279200030000 & $2,632.0$ & $3,081.9$ & 7 & 3,223 \\
\hline 8 & U.S. Navy & Knifeblade 1 & 50119100120000 & 312.0 & $1,490.0$ & 6 & 6,777 \\
\hline 9 & $\mathrm{BP}$ & Kuparuk Unit 1 & 50287100180000 & $5,529.0$ & $5,920.0$ & 9 & 7,090 \\
\hline 10 & Sinclair & Little Twist Unit 1 & 50287100220000 & 942.0 & $3,609.0$ & 4 & 8,895 \\
\hline 11 & U.S. Navy & Meade 1 & 50163100020000 & $1,795.0$ & $2,950.0$ & 2 & 4,560 \\
\hline 12 & U.S. Navy & Oumalik Test 1 & 50119100050000 & 916.0 & $2,758.3$ & 17 & 4,711 \\
\hline 13 & Husky & Seabee 1 & 50287200070000 & 270.0 & $2,110.0$ & 7 & 6,564 \\
\hline 14 & BP & Trailblazer A1 & 50103203640000 & $2,972.0$ & $3,454.0$ & 4 & 1,402 \\
\hline 15 & BP & Trailblazer H1 & 50103203690000 & $2,760.0$ & $3,090.0$ & 3 & 1,525 \\
\hline 16 & U.S. Navy & Topagoruk 1 & 50279100330000 & 302.0 & $2,097.0$ & 10 & 2,748 \\
\hline 17 & Texaco & Tulugak 1 & 50057200010000 & $1,700.0$ & $2,510.0$ & 3 & 8,030 \\
\hline 18 & Husky & Tunalik 1 & 50301200010000 & $3,288.0$ & $5,560.6$ & 2 & 3,036 \\
\hline 19 & U.S. Navy & Umiat Test 11 & 50287100110000 & $2,048.0$ & $2,992.0$ & 37 & 6,301 \\
\hline 20 & U.S. Navy & Umiat Test 1 & 50287100010000 & $1,335.0$ & $2,996.0$ & 6 & 6,614 \\
\hline 21 & U.S. Navy & Umiat Test 2 & 50287100020000 & 413.0 & 969.0 & 4 & 6,469 \\
\hline 22 & U.S. Navy & Umiat Test 7 & 50287100070000 & 834.0 & $1,370.0$ & 5 & 6,543 \\
\hline 23 & U.S. Navy & Umiat Test 8 & 50287100080000 & 507.0 & 711.0 & 2 & 6,374 \\
\hline 24 & U.S. Navy & Wolf Ck 2 & 50119100090000 & $2,511.0$ & $3,520.0$ & 20 & 7,071 \\
\hline 25 & U.S. Navy & Wolf Ck 3 & 50119100100000 & $1,660.0$ & $2,362.0$ & 17 & 7,191 \\
\hline
\end{tabular}

Table 3-4. Classification of grain and intergranular parameters.
A. Quartzose grains
C. Lithic grains
$\mathrm{Q}_{\mathrm{m}}=$ Monocrystalline quartz
$L_{s}=$ Sedimentary rock fragments (including chert)
$Q_{p}=$ Polycrystalline quartz (including chert)
$L_{v}=$ Volcanic rock fragments
$Q_{t}=$ Total quartzose grains $\left(Q_{m}+Q_{p}+\right.$ chert $)$
$\mathrm{Lm}_{\mathrm{m}}=$ Metamorphic rock fragments
$L_{p}=$ Plutonic rock fragments
B. Feldspar grains
$\mathrm{P}=$ Plagioclase
$\mathrm{K}=$ Potassium feldspar
$F=$ Total feldspar grains $(P+K)$
$\mathrm{L}_{\mathrm{sm}}=$ Sedimentary and metasedimentary rock fragments
$\mathrm{Lvm}_{\mathrm{v}}=$ Volcanic and metavolcanic rock fragments
$L=$ Lithic grains $\left(L_{s}+L_{v}+L_{m}+L_{p}\right)$
$L_{t}=$ Total lithic grains $\left(L+Q_{p}\right)$
D. Intergranular components
$\phi=$ Total porosity
$\mathrm{C}=$ Total cement
$M=$ Matrix + clay laminae $/$ burrows 
the framework fraction, respectively. Other significant detrital components include chert (11 percent), plagioclase (9 percent), and $\mathrm{K}$-feldspar (5 percent). Lithic detritus consists largely of sedimentary (detrital carbonate, mudstone, argillite) and metamorphic (phyllite, quartzite) rock fragments. Organic matter and micas are accessory detrital components.

Overall reservoir quality of the very-fine-grained sandstones is good to very good with an average air permeability of $43 \mathrm{md}$ ( $36 \mathrm{md}$ Klinkenberg permeability) and average porosity of 23 percent (fig. 3-11). They typically are lightly cemented, containing an average of 3 percent carbonate cements, mostly siderite and minor ankerite. Kaolinite is a patchy, pore-filling cement averaging 1 percent of the bulk rock; a few overgrowths (<1 percent) were observed on detrital quartz grains. Detrital matrix is variable, ranging from 3 to 12 bulk percent, sometimes concentrated along diffuse laminae. The average intergranular volume (IGV) is 24 percent, similar to that of the other sandstones.
Nine samples of this petrofacies belong to the planeparallel laminated sandstone (Slf) facies, five to the ripple cross-laminated sandstone (Sr) facies, and two to the heterolithic sandstone and mudstone (SFh) facies (table 3-1).

\section{FINE-GRAINED SANDSTONE PETROFACIES}

The fine-grained sandstone petrofacies is represented by 21 chert-rich litharenites (fig. 3-8). They have an average modal composition of $\mathrm{Q}_{\mathrm{t} 57} \mathrm{~F}_{11} \mathrm{~L}_{32}, \mathrm{Q}_{\mathrm{m} 19} \mathrm{~F}_{10} \mathrm{~L}_{\mathrm{t} 71}, \mathrm{Q}_{\mathrm{m} 64} \mathrm{P}_{21} \mathrm{~K}_{15}$, $\mathrm{Q}_{\mathrm{p} 55} \mathrm{~L}_{\mathrm{vm} 9} \mathrm{~L}_{\mathrm{sm} 32}$ (fig. 3-4, appendix 3-F), and a plagioclase/ total feldspar $(\mathrm{P} / \mathrm{F})$ ratio of 0.59 . The average grain size (fig. 3-5, appendix 3-G) of this petrofacies is $0.20 \mathrm{~mm}$ (upper fine), with an average Folk sorting (Folk, 1974) of 0.97 (moderate). Chert and monocrystalline quartz $\left(\mathrm{Q}_{\mathrm{m}}\right)$ with dominantly straight to slightly undulose extinction are the two dominant framework components, averaging 26 and 17 percent of the framework fraction, respectively. Chert is largely of the common microcrystalline variety; other varieties include micaceous-argillaceous, calcareous-dolomitic, and microporous chert. Polycrystalline quartz $\left(\mathrm{Q}_{\mathrm{p}}\right)$


Figure 3-6. Photomicrographs of siltstone petrofacies; sample from 1,160.3 ft. A. General view of siltstone, showing an abundance of detrital clay (yellow arrows). Plane-polarized light. B. Same view as A, but with crossed polars. C. Detailed view of siltstone in which the framework fraction consists largely of monocrystalline quartz (q). Plane-polarized light. D. Same view as $C$, but with crossed polars. 
averages 9 percent of the detrital framework and consists of both grains with 2-5 crystals (plutonic and high-rank metamorphic provenance) and greater than 5 crystals (low-rank metamorphic provenance; Basu and others, 1975; Blatt and others, 1980; Blatt, 1982; Boggs, 2009). Feldspar comprises roughly 9 percent of the framework, consisting of slightly more plagioclase than K-feldspar. Plagioclase shows varying degrees of alteration and dissolution, while K-feldspar is largely unaltered. Lithic fragments (excluding chert) comprise approximately 30 percent of the rock framework, consisting of mudstonesiltstone, felsic volcanic and plutonic grains, quartzite, phyllite, and detrital carbonate. Micas, heavy minerals, and dispersed organic grains occur in trace amounts.

Overall reservoir quality of these sandstones is very good to excellent with an average air permeability of 210 md (193 md Klinkenberg permeability) and average porosity of 25 percent (fig. 3-11). They are largely uncemented and contain only limited detrital matrix. Minor cements include patchy, pore-filling kaolinite and siderite, and occasional ankerite. Siderite locally replaces oversized clay grains (probable clay rip-up clasts) and occurs along mica cleavage, causing the mica to be splayed out. A few overgrowths were observed on monocrystalline quartz grains. The average intergranular volume (IGV) is 23 percent, suggesting that most porosity loss was through compaction.

Fourteen samples of this petrofacies belong to the plane-parallel laminated sandstone (slf and Slm) facies, four to the cross-bedded sandstone (Sx) facies, and three to the massive sandstone (Sm) facies (table 2).

\section{MEDIUM-GRAINED SANDSTONE PETROFACIES}

The medium-grained sandstone petrofacies is represented by three samples that are chert-rich litharenites (fig. 3-9). They have an average modal composition of $\mathrm{Q}_{\mathrm{t70}} \mathrm{F}_{8} \mathrm{~L}_{22}, \mathrm{Q}_{\mathrm{m} 19} \mathrm{~F}_{8} \mathrm{~L}_{\mathrm{t} 73}, \mathrm{Q}_{\mathrm{m} 69} \mathrm{P}_{23} \mathrm{~K}_{8}, \mathrm{Q}_{\mathrm{p} 73} \mathrm{~L}_{\mathrm{vm} 8} \mathrm{~L}_{\mathrm{sm} 19}$ (fig. 3-4, appendix $3-\mathrm{F})$ and a plagioclase/total feldspar $(\mathrm{P} / \mathrm{F})$ ratio of 0.76 . Their average grain size (fig. 3-5, appendix 3-G) is $0.27 \mathrm{~mm}$ (lower medium), with an average Folk sorting (Folk, 1974)
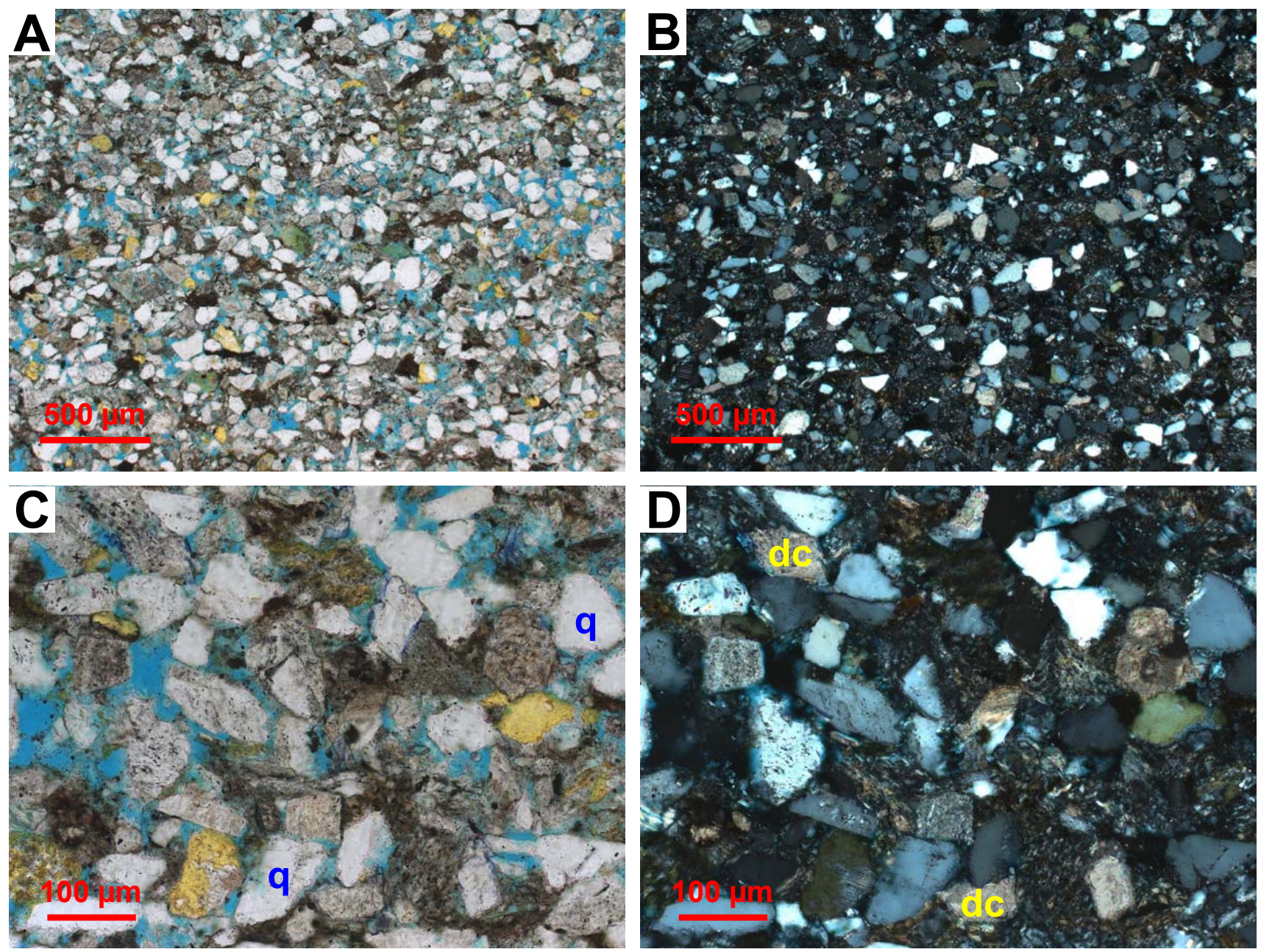

Figure 3-7. Photomicrographs of very-fine-grained sandstone petrofacies; sample from 1,072.1 ft. A. General view, showing a moderately compacted framework lacking significant cements. Plane-polarized light. B. Same view as A, but with crossed polars. C. Detailed view of sandstone, showing abundance of monocrystalline quartz (q). Plane-polarized light. D. Same view as $\mathrm{C}$, but with crossed polars. Note detrital carbonate grains (dc). 
of 0.97 (moderate). Chert and monocrystalline quartz $\left(\mathrm{Q}_{\mathrm{m}}\right)$ are the two dominant framework components, averaging 44 and 17 percent of the framework fraction, respectively. Although chert consists largely of the common, clay-poor, microcrystalline variety, grains of micaceous-argillaceous chert are not uncommon and a few grains of the calcareous-dolomitic and microporous variants were noted. Monocrystalline quartz typically has straight to slightly undulose extinction (fig. 3-9). Polycrystalline quartz $\left(Q_{p}\right)$ averages almost 5 percent of the detrital framework and consists largely of grains with 2-5 crystal units. Feldspar comprises roughly 8 percent of the framework, consisting of three times more plagioclase than K-feldspar. Plagioclase shows varying degrees of alteration and dissolution, while K-feldspar is largely unaltered. Lithic fragments (excluding chert) comprise one-fifth of the rock framework and consist of a variety of lithologies including mudstonesiltstone, felsic volcanic and plutonic grains, quartzite, phyllite, and detrital carbonate. Micas (muscovite, biotite, and chlorite) and heavy minerals occur in trace amounts. Minor organic material occurs as dispersed grains ("coffee grounds") and discontinuous laminae.

Overall reservoir quality of these sandstones is excellent with an average air permeability of $735 \mathrm{md}(695 \mathrm{md}$ Klinkenberg permeability) and average porosity of 26 percent (fig. 3-11). They are largely uncemented and contain little detrital matrix. Minor cements include patchy, porefilling kaolinite and siderite. The average intergranular volume (IGV) is 26 percent, suggesting that most porosity loss was through compaction.

All three samples of this petrofacies belong to the plane-parallel laminated sandstone (Slm) facies (table 3-1).

\section{CARBONATE-CEMENTED SANDSTONE PETROFACIES}

The carbonate-cemented sandstone petrofacies is represented by the two shallowest samples (181.9 and $339.0 \mathrm{ft}$ ), which are extensively cemented by ankerite.
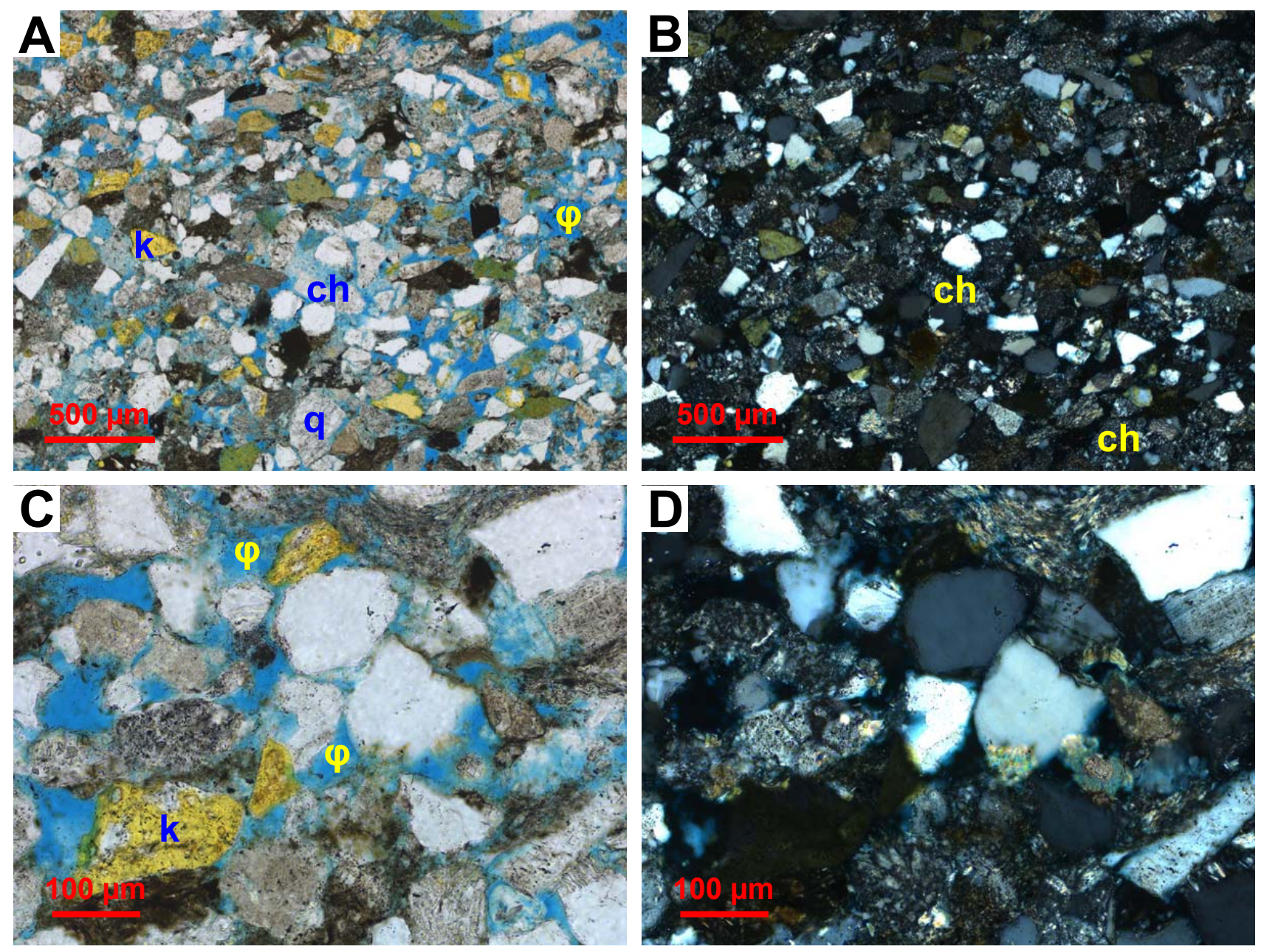

Figure 3-8. Photomicrographs of fine-grained sandstone petrofacies; sample from $654.15 \mathrm{ft}$. A. General view, showing abundance of intergranular pores $(\phi)$, quartz (q), K-feldspar (k), and chert (ch), which is best seen under crossed polars. Plane-polarized light. B. Same view as A, but with crossed polars, showing abundant chert grains (ch). C. Detailed view, showing common intergranular pores $(\phi)$. Note detrital K-feldspar (k). Plane-polarized light. D. Same view as C, but with crossed polars. 
The abundant cement is the key petrographic characteristic that groups these samples into the same petrofacies (fig. 3-10). The two samples have an average grain size (fig. 3-4, appendix 3-G) of $0.07 \mathrm{~mm}$ (lower very fine) and an average Folk sorting (Folk, 1974) of 1.72 (poor). Their detrital composition is similar to other very-fine-grained sandstones from the well, with an average modal composition of $\mathrm{Q}_{t 60} \mathrm{~F}_{15} \mathrm{~L}_{25}, \mathrm{Q}_{\mathrm{m} 35} \mathrm{~F}_{15} \mathrm{~L}_{\mathrm{t} 50}, \mathrm{Q}_{\mathrm{m} 70} \mathrm{P}_{15} \mathrm{~K}_{15}, \mathrm{Q}_{\mathrm{p} 51} \mathrm{~L}_{\mathrm{vm} 4} \mathrm{~L}_{\mathrm{sm} 45}$ (fig. 3-4, appendix 3-F) and a plagioclase/total feldspar (P/F) ratio of 0.50 . Monocrystalline quartz $\left(\mathrm{Q}_{\mathrm{m}}\right)$ is the dominant framework component in both samples, averaging 31 percent of the framework. Other significant detrital components include chert (13 percent), polycrystalline quartz (10 percent), plagioclase (7 percent), and K-feldspar (7 percent). Lithic grains consist largely of sedimentary (detrital carbonate, mudstone, argillite) and metamorphic (phyllite, quartzite) rock fragments. Organic material and micas are minor components.
Overall reservoir quality of these sandstones is very poor to negligible with an average air permeability of $0.002 \mathrm{md}$ ( $0.0005 \mathrm{md}$ Klinkenberg permeability) and average porosity of 2.7 percent (fig. 3-11). They are highly cemented by ankerite (provisional identification is based on distinctive turquoise color resulting from potassium ferricyanide stain), which is virtually the only cement in the sandstones, averaging 43 percent of the bulk rock. The similarity in detrital mineralogy between these highly cemented and the other relatively uncemented veryfine-grained sandstones suggests that cementation was either (1) passively pore-filling with little replacement of detrital grains, or (2) unselective in grain replacement. While some grains do show evidence of etching or partial replacement (fig. 3-10C), the bulk of cementation is interpreted to have been passive. Matrix content varies between the two samples and may be related to grain size. The lower very-fine-grained $(0.078 \mathrm{~mm})$ sandstone at
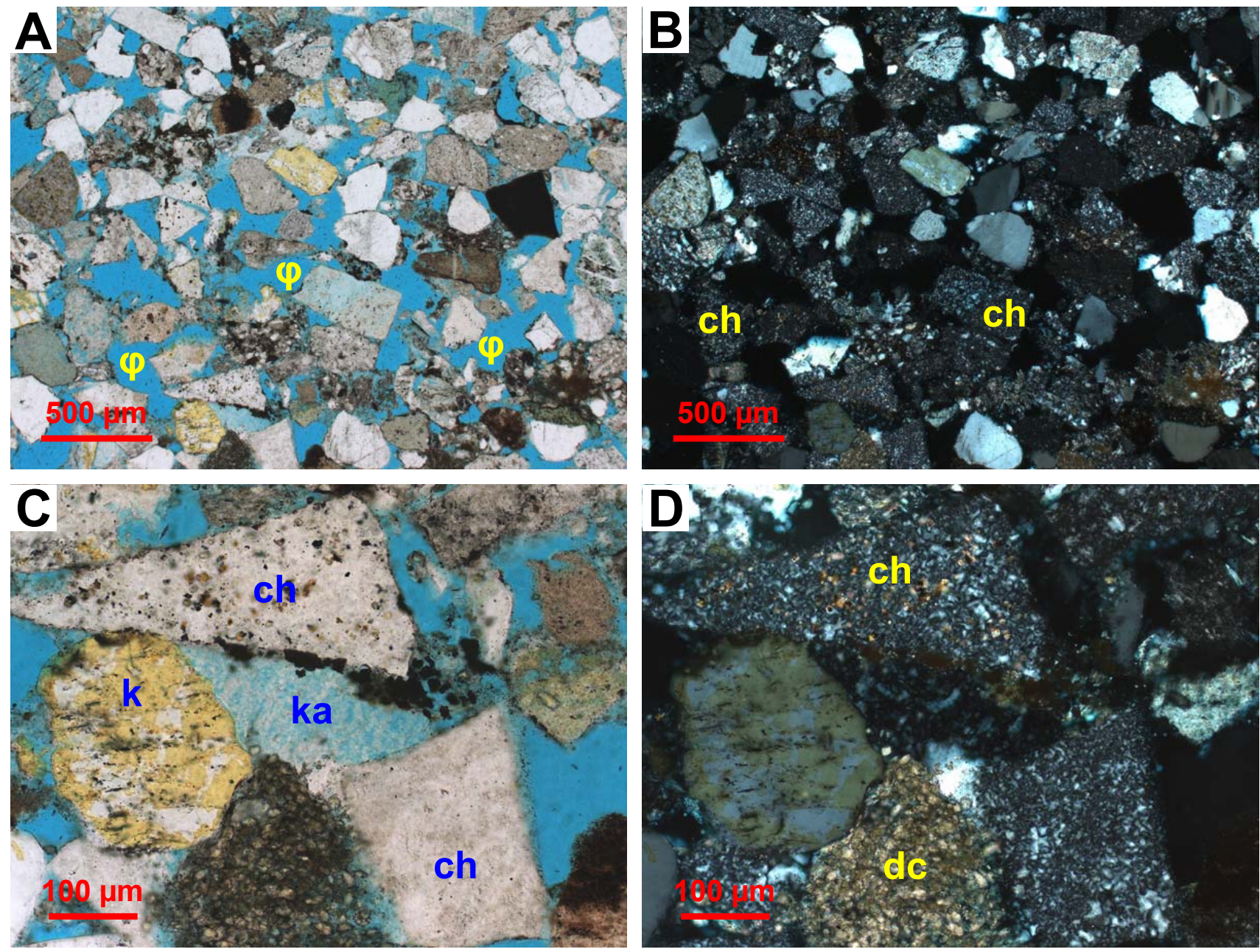

Figure 3-9. Photomicrographs of medium-grained sandstone petrofacies; sample from 1,128.1 ft. A. General view, showing extensive intergranular porosity $(\phi)$. Plane-polarized light. B. Same view as A, except with crossed polars, showing chert (ch) is the dominant framework component. C. Detailed view, showing authigenic kaolinite (ka) filling pore between grains of chert (ch) and K-feldspar (k). Plane-polarized light. D. Same view as C, except with crossed polars; note chert (ch) and detrital carbonate (dc). 
$181.9 \mathrm{ft}$ contains 9.5 percent matrix while the upper veryfine-grained $(0.106 \mathrm{~mm})$ sample at $339 \mathrm{ft}$ contains only 2 percent matrix. The average intergranular volume (IGV) of 49 percent is close to, or greater than, the presumed initial depositional porosity, suggesting that cementation was very early (syndepositional to very shallow burial) and that virtually no porosity was lost through compaction.

One sample of this petrofacies belongs to the massive sandstone $(\mathrm{Sm})$ facies, the other to the ripple cross-laminated sandstone (Sr) facies (table 3-1).

\section{GRAIN-SIZE TRENDS}

The Wainwright siltstones and sandstones exhibit well-developed relationships among texture, composition, and reservoir quality. In particular, grain size has a high degree of correlation with several parameters including porosity, permeability, and grain composition, as illustrated by chert, monocrystalline quartz, and VRFs.
It should be noted that because grain size is given in phi $(\varphi)$, which is defined as $-\log _{2}$ (grain size ${ }_{\mathrm{mm}}$ ), a positive correlation between variables (for example, permeability increases with increasing grain size) is actually reported as a negative value of the Pearson product-moment correlation coefficient ( $r$ ) (table 3-2). Likewise, to best display a linear relationship among variables, the ordinate (y-axis) on several of the cross-plots is commonly displayed with a logarithmic scale.

A good correlation exists between grain size and reservoir quality as expressed by porosity and permeability. There is a pronounced linear relationship between grain size and porosity, with a Pearson product-moment correlation coefficient ( $r$ ) of - 0.94 (table 3-2). The medium- and fine-grained sandstones have average porosity of 26 and 25 percent, respectively, while the siltstone porosity averages 15 percent (fig. 3-12A). To ascertain whether this trend is exhibited by Nanushuk Formation sandstones from other localities, data from 25 additional North Slope wells (table
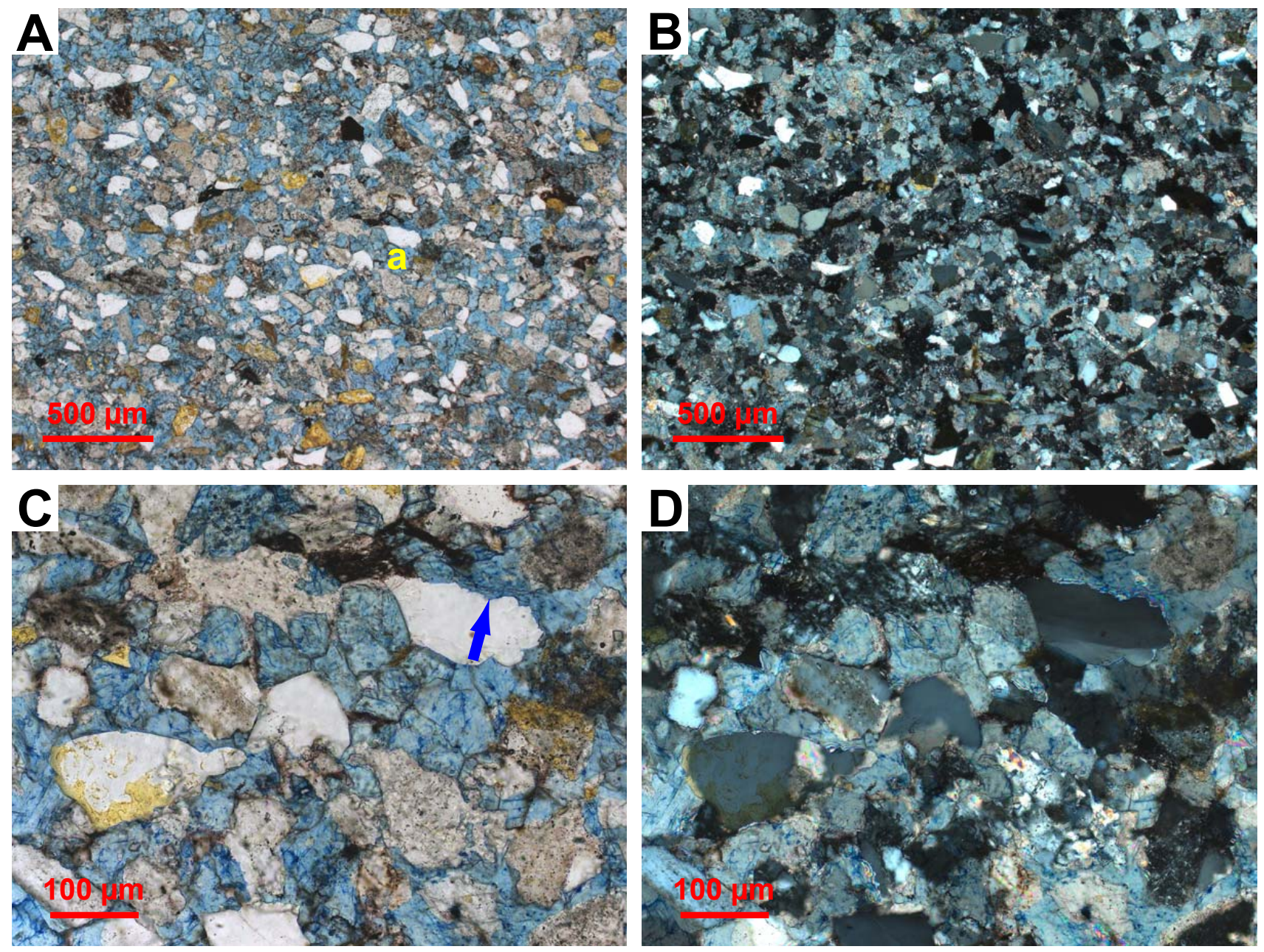

Figure 3-10. Photomicrographs of carbonate-cemented sandstone petrofacies; sample from 335.0 ft. A. General view showing extensive ankerite (a) cement. An intergranular volume (IGV) approaching 45 percent suggests that cementation occurred shortly after deposition and prior to significant burial. Plane-polarized light. B. Same view as A, except with crossed polars. C. Detailed view, showing irregular edges of grains (blue arrow), suggesting some grain replacement might have occurred. Plane-polarized light. D. Same view as C, except with crossed polars. 
3-3) were included in the plots for comparison. Based on this limited dataset, it appears this trend is not evident in the regional Nanushuk data, where sandstones of equivalent grain size have substantially lower porosity with a greater standard deviation. There is also a pronounced linear relationship between grain size and permeability, with an average permeability of $735 \mathrm{md}$ in the mediumgrained sandstones and only $1 \mathrm{md}$ in the siltstones (fig. 3-12B). It is universally recognized that with all other factors being equal, coarser sediments have larger pore throats, resulting in enhanced fluid mobility (Beard and Weyl, 1973). For the regional Nanushuk samples, permeability for a given grain size is substantially lower and exhibits greater variability than permeability exhibited by the Wainwright samples. The reason for the disparity in the reservoir quality versus grain size relationships between the Wainwright and regional Nanushuk sandstones is interpreted to reflect differences in burial and is discussed in the following section.

The relationship between grain size and framework composition is well illustrated by detrital chert (correlation coefficient of -0.93), with the medium-grained sandstones averaging more than 30 percent (whole rock) chert, while the siltstones average slightly over 2 percent (fig. 3-12C). The regional Nanushuk sandstones show a similar correlation, suggesting the grain size versus
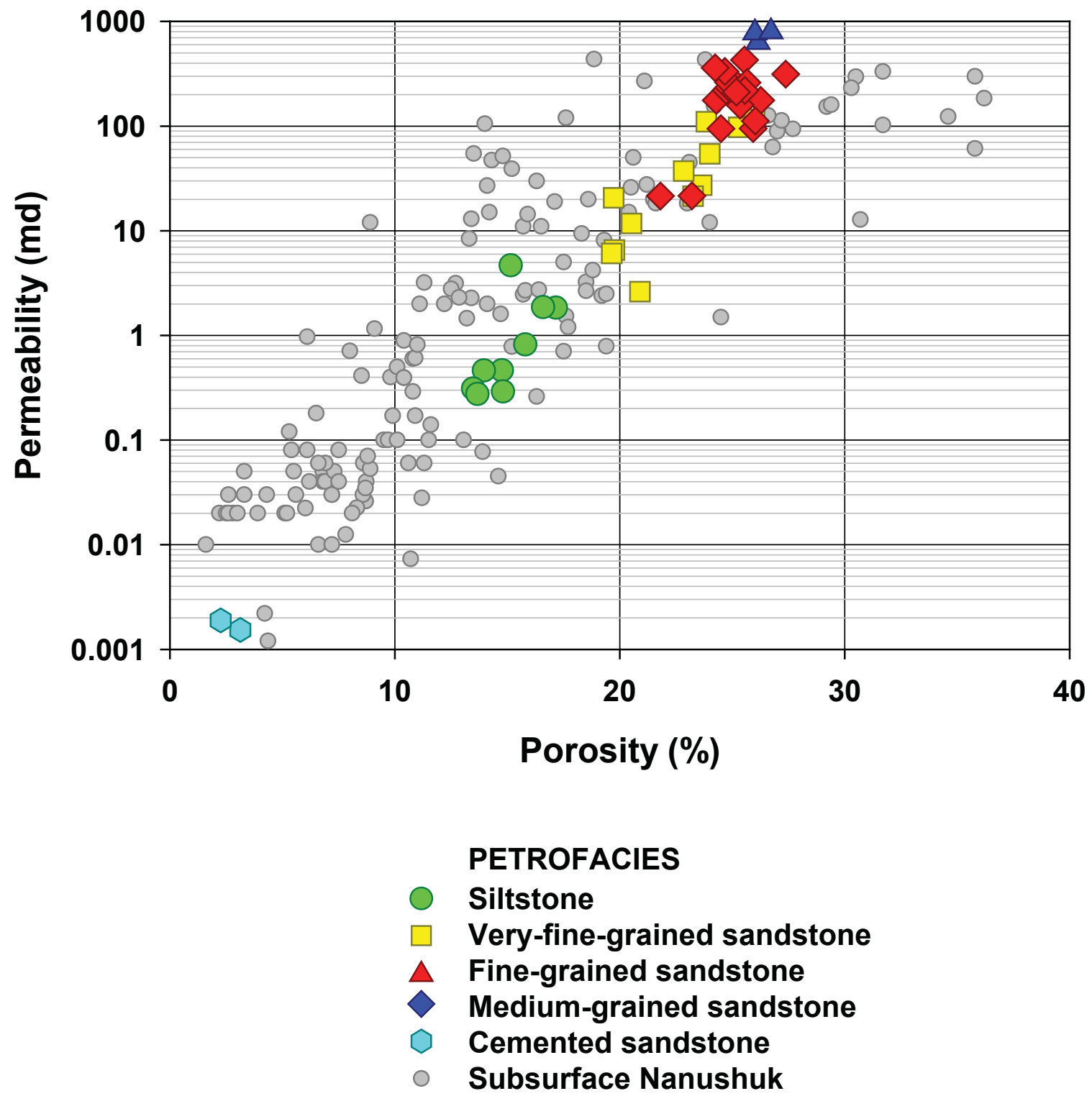

Figure 3-11. Porosity-permeability cross plot showing reservoir quality of Wainwright and regional Nanushuk sandstones included in this report. Of the non-cemented Wainwright samples, the medium- and fine-grained sandstones have the best reservoir quality (very good to excellent), while the siltstones have the poorest (moderately poor to poor). The carbonate-cemented rocks have negligible reservoir quality. 

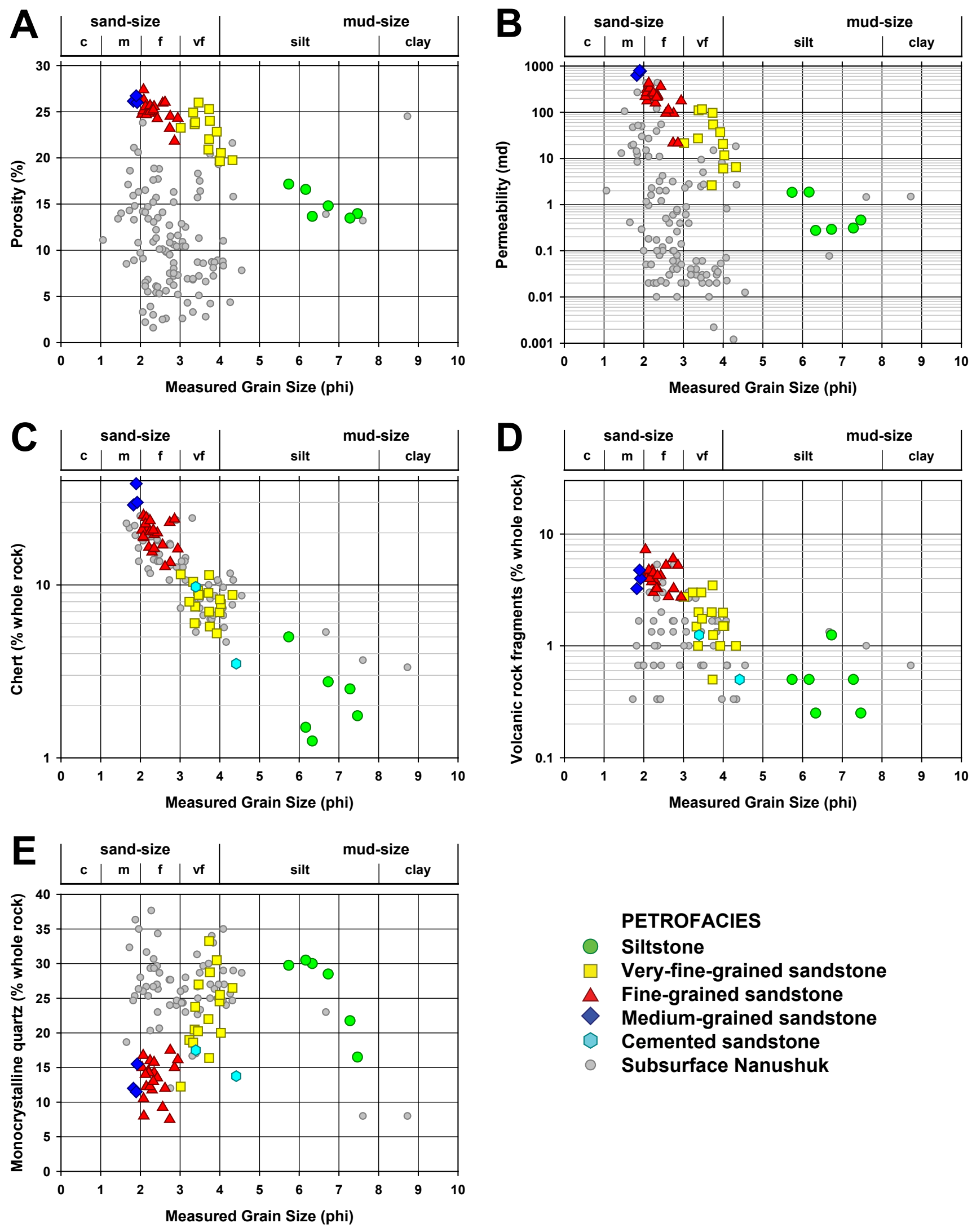
Figure 3-12 (left). Cross plots of grain size in phi $(\phi)$ versus several petrophysical and compositional parameters. Because grain size is given in phi $(\phi)$, which is defined as $-\log _{2}$ (grain size ${ }_{\mathrm{mm}}$ ), a positive correlation between variables (permeability increases with increasing grain size) is actually reported as a negative value of the Pearson product-moment correlation coefficient ( $r$ ). Likewise, to best display a linear relationship between variables, the ordinate (y-axis) is commonly displayed with a logarithmic scale. A. Porosity-grain-size plot, showing the well-developed relationship between the two variables ( $r$ $=-0.93$ ) for the Wainwright samples. The regional Nanushuk sandstones do not show as good a correlation largely because they have been subjected to deeper burial. B. Permeability-grain-size plot shows a similar very good correlation between the two variables for the Wainwright samples that is not shared by the regional Nanushuk sandstones. C. Chert-grainsize plot showing very good correlation for both the Wainwright and regional samples. Chert preferentially resides in the coarser fraction of the detritus. D. Volcanic rock fragments (VRF)-grain-size plot showing good correlation for Wainwright and regional samples. E. Monocrystalline quartz $\left(Q_{m}\right)$-grain-size plot, showing good correlation for the Wainwright and regional sandstones. Wainwright siltstones have lower quartz content due to dilution by abundant detrital clay.

chert relationship may be universal among Nanushuk sandstones. A possible explanation for this trend may lie in the origin of the chert grains.

Potential sources include the Mississippian-Pennsylvanian Lisburne Group, mid-Pennsylvanian-Permian Imnaitchiak chert, and Triassic Otuk Formation (Mull, 1995). Large (cobble- to boulder-sized) chert nodules are widespread in the Lisburne carbonates and Imnaitchiak chert, while thin-bedded (2-6-inch-thick beds) chert predominates in the Otuk Formation (Mull, 1995). In either case, as nodular and/or bedded chert clasts weather and erode from the host lithologies, their size would dictate concentration in the coarsest detritus. With continued transport and abrasion, chert grains of silt to very-fine sand size should ultimately be produced if its solubility were comparable to that of quartz; but that is not the case in these Nanushuk sandstones. Perhaps in these finer fractions the higher solubility of chert relative to monocrystalline quartz (Aase and others, 1996; Jahren and Ramm, 2000), combined with greater surface area, may result in its selective dissolution, thereby increasing the relative abundance of quartz. Bedded chert typically contains clay and other impurities compared to modular chert, which is usually isotropic (Mull, 1995), possibly making the former more susceptible to dissolution (Wartes, oral commun.). A similar grain-size relationship is also seen in Ivishak sandstones from the North Slope of Alaska, where chert content is thought to be related to distance of transport (Atkinson and others, 1990).

A similar, although less pronounced, relationship exists between grain size and volcanic rock fragment (VRF) content where the medium- and fine-grained sandstones average 4 percent (whole rock) VRFs while the siltstones average 0.5 percent (fig. 3-12D). The regional Nanushuk data for VRFs show similar abundance (0.2-5 percent), although the correlation is not as convincing. In the cases of both chert and VRFs, the lithic grains are concentrated in the coarser detritus.

A complementary relationship exists for grain size and monocrystalline quartz, where the medium-grained sandstones average 13 percent (whole rock) $Q_{m}$ while the siltstones average 26 percent (fig. 3-12E). The correlation coefficient of 0.67 for the entire dataset increases to 0.80 for just the sand fraction (siltstones excluded). The regional Nanushuk data for $Q_{m}$ are similar (8-38 percent spread), although the correlation is less pronounced.

\section{RESERVOIR QUALITY}

Reservoir quality (porosity and permeability) of the Wainwright sandstones varies widely from very poor (cemented sandstones) to excellent (medium-grained sandstone) and, with the exception of the cemented samples, is largely controlled by grain size, which is a proxy for depositional environment. The porosity-permeability trend for the Wainwright samples parallels that of the regional Nanushuk trend, although a larger proportion of the regional sandstones have poor to very poor reservoir quality (fig. 3-11). This disparity in reservoir quality results from differences in burial, specifically the maximum burial the rocks experienced. The Wainwright test well is located along the northern Alaska coastline, where the amount of removed overburden is estimated at $2,762 \mathrm{ft}$ (fig. 3-13, modified from Burns and others, 2005). That amount, added to the current burial depths of Wainwright samples, yields maximum depths of burial $\left(D_{\max }\right)$ ranging from 2,944 to $4,263 \mathrm{ft}$, generally considered shallow to moderate burial. In contrast, many of the wells in the regional dataset are up to $100 \mathrm{mi}$ south of the Barrow arch, where estimates of removed overburden approach 9,000 $\mathrm{ft}$ (fig. 3-13, table 3-3). As a result, the maximum depth of burial for many of these samples approaches $10,000 \mathrm{ft}$ (fig. 3-14), which is traditionally considered deep burial.

Differences in reservoir quality are graphically illustrated in a PFC (porosity-framework-cement) diagram (fig. 3-15), a technique originally proposed by Franks and Lee (1994). The Wainwright sandstones largely plot in the field of "compacted reservoir" while the siltstones fall into the "compacted non-reservoir" area of the diagram. The regional Nanushuk sandstones are largely confined to the "compacted reservoir" and "compacted non-reservoir" fields, although a few samples plot in the "preserved reservoir" portion of the diagram. A limited number of the Wainwright and regional samples lie in the "cemented non-reservoir" field, attesting that porosity is largely destroyed by compaction. This is confirmed by a cross plot of compactional porosity loss (COPL; Lundegard, 1992) versus cementational porosity loss (CEPL), which 


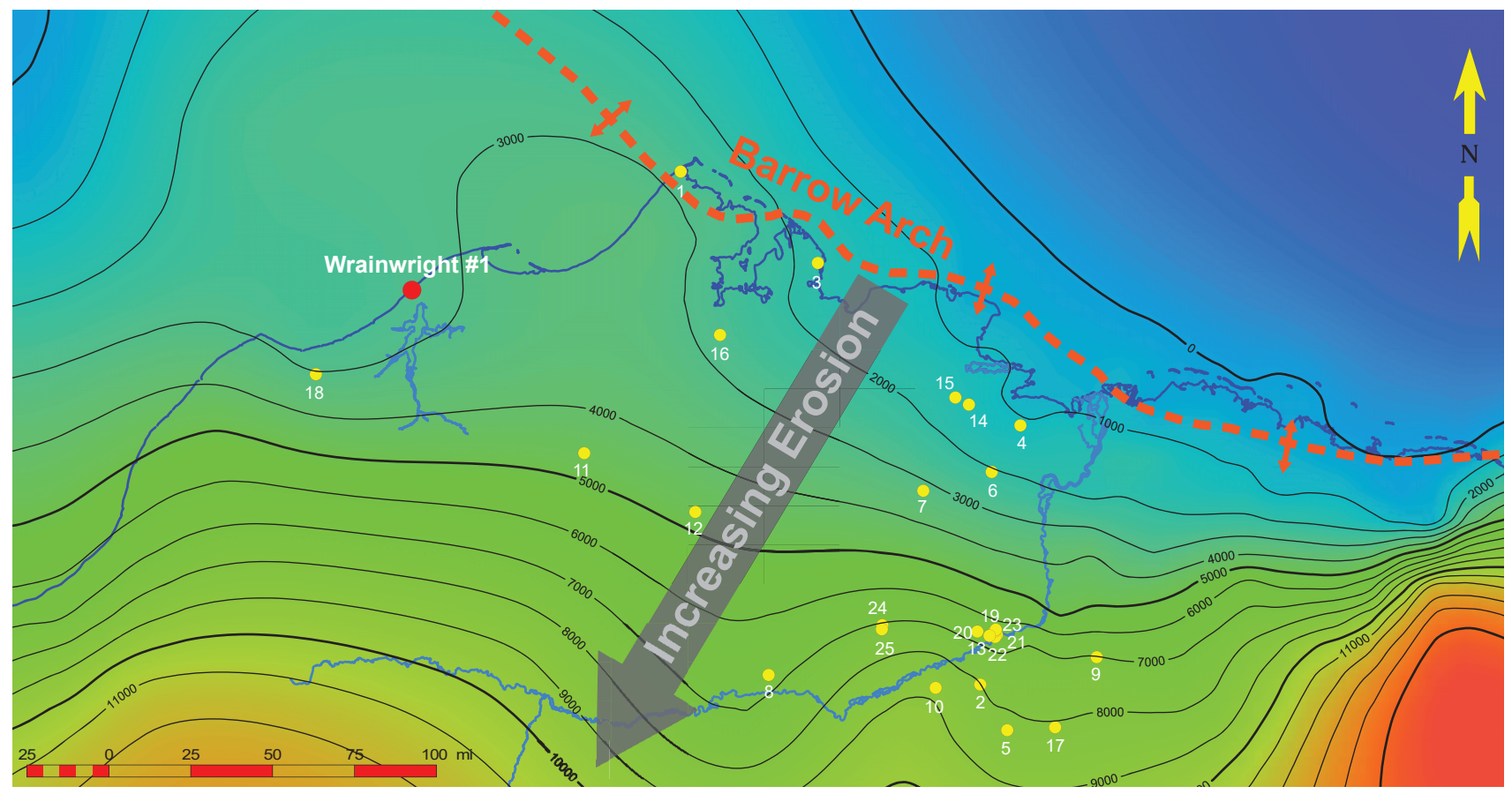

Figure 3-13. Contoured map of the central North Slope of Alaska, showing estimates of the amount (in feet) of Brookian strata removed by erosion. Red dot shows the location of the Wainwright \#1 test well; yellow dots show locations of 25 wells for which data are included in scatter and ternary plots (table 3-3). The large arrow shows the regional trend of increasing amounts of erosion to the south. Contours were generated from the data of Burns and others (2005) using the GeoAtlas mapping module of GeoGraphix (minimum curvature algorithm with smallest feature radius of 50,000 $\mathrm{ft}$ and radius of influence of $1,000,000 \mathrm{ft}$ ).

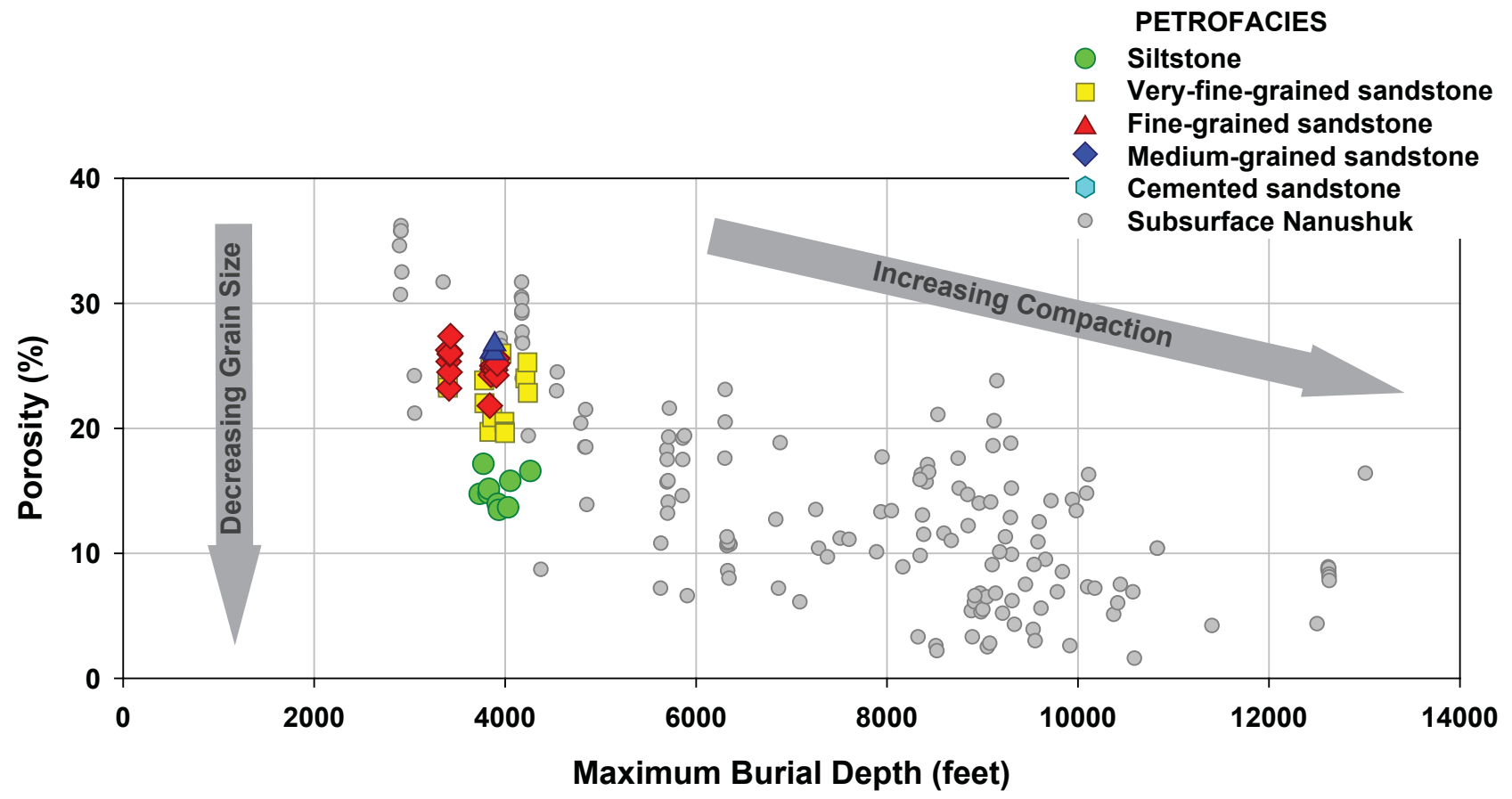

Figure 3-14. Cross plot of porosity versus maximum burial depth $\left(D_{\max }\right)$ for the Wainwright and regional Nanushuk siltstones and sandstones. The Wainwright samples have $D_{\max }$ values ranging from 2,944 to 4,263 ft, while most of the regional Nanushuk samples were buried to greater depths $\left(D_{\max }>6,000 \mathrm{ft}\right)$. The arrows point out the two major controls on Nanushuk reservoir quality: Grain size and compaction. At any given value of $D_{\text {max }}$, reservoir quality is largely controlled by grain size, which is a proxy for environment of deposition. At the regional scale, compaction has a significant effect on reservoir quality. 
shows a similar relationship (fig. 3-16). The vast majority of Wainwright and regional Nanushuk sandstones have COPL values of 25-45 percent with corresponding CEPL values of less than 8 percent, confirming that cementation does not play a major role in porosity destruction. Reservoir quality is largely controlled by two separate processes: Local grain-size effects and regional compaction (fig. 3-14). On the local scale at any given geographic location, porosity and permeability are mainly a function of grain size, which is determined by the sedimentary environment where the detritus was deposited. From a regional perspective, porosity and permeability are reduced as the sediments, regardless of depositional environment, are buried to greater depths. Hence, there is a decrease in overall reservoir quality from north to south corresponding to greater amounts of burial and removed overburden. In areas that have not seen significant burial, such as the vicinity of the Barrow arch, there is usually a large spread in porosity and permeability controlled almost exclusively by grain size. In areas that have undergone deep burial, such as the vicinity of the Brooks Range deformation front, the variability of porosity and permeability in any given core is reduced, being controlled by both grain size and compaction (fig. 3-14).

\section{ф}

\section{$45 \%$}

$\mathbf{F}$

$100 \%$

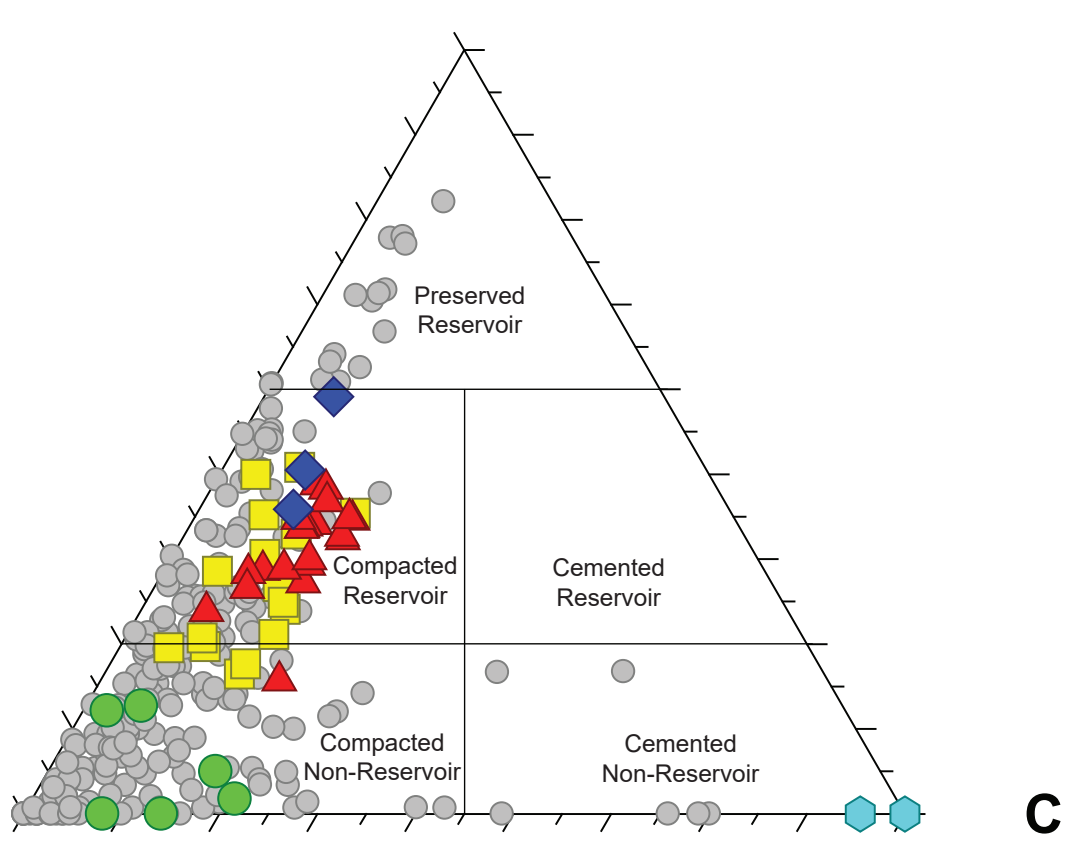

$45 \%$

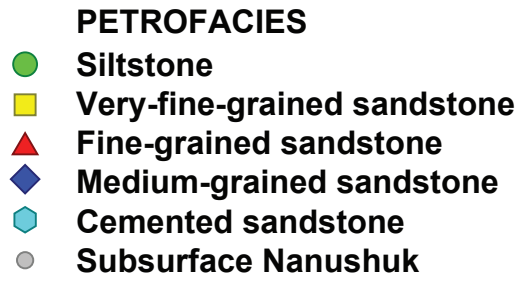

Figure 3-15. Porosity-Framework-Cement $(\phi-F-C)$ ternary diagram showing reservoir quality of the Wainwright and regional Nanushuk siltstones and sandstones. The Wainwright siltstones plot in the "compacted non-reservoir" area of the diagram, while most of the Wainwright sandstones plot in the "compacted reservoir" field. The regional Nanushuk sandstones plot mainly in the "compacted non-reservoir" and "compacted reservoir" fields, although a few are in the "preserved reservoir" and "cemented non-reservoir" fields. This confirms that porosity loss in Nanushuk sandstones is dominantly through compaction. Diagram modified from Franks and Lee (1994); used with permission. 

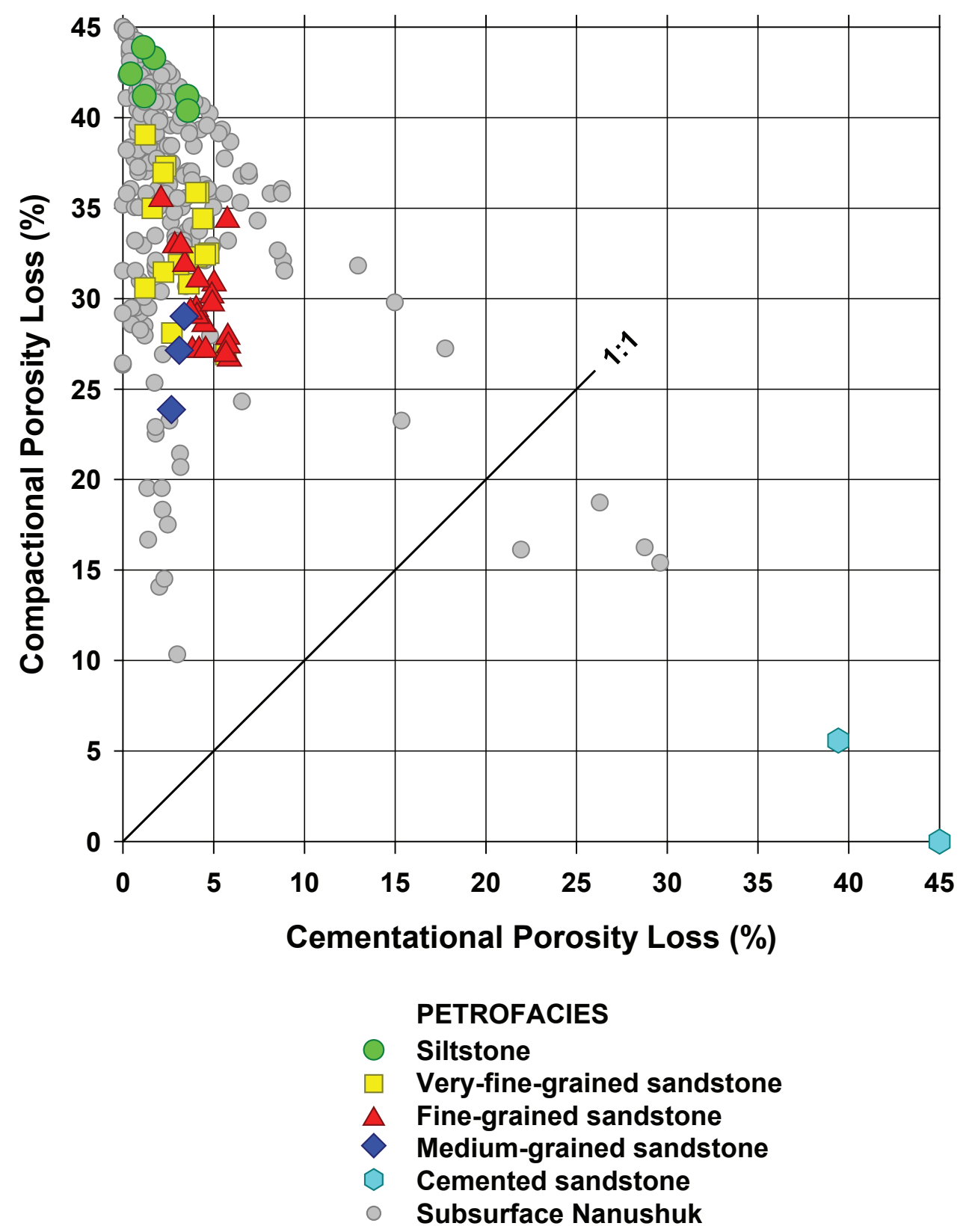

Figure 3-16. Cross plot of compactional porosity loss versus cementational porosity loss for Wainwright and regional Nanushuk siltstones and sandstones. Samples with cementational porosity loss greater than 45 percent (Wainwright \#1, $181.9 \mathrm{ft}$ ) are arbitrarily set to the assumed maximum intergranular volume of 45 percent. The diagonal line (1:1) represents equal porosity loss by compaction and cementation. Most of the porosity loss in all samples was through compaction. Diagram modified from Lundegard (1992). 


\section{ACKNOWLEDGMENTS}

Funding for this work was provided by the State of Alaska; additional funding for routine core analyses was provided by the U.S. Geological Survey. David Houseknecht and Ken Bird provided access to the core plug trim-ends from which Mark Mercer of Petrographics, LLC, provided superb, high-quality thin sections. David L. LePain reviewed an early version of the manuscript and provided many helpful suggestions. Insightful formal reviews by Marwan A. Wartes, Paul J. McCarthy, and Nina T. Harun were very helpful in improving the final report.

\section{REFERENCES CITED}

Aase, N.E., Bjorkum, P.A., and Nadeau, P.H., 1996, The effect of grain-coating microquartz on preservation of reservoir porosity: American Association of Petroleum Geologists Bulletin, v. 80, no. 10, p. 1,654-1,673. doi:10.1306/64EDA0F0-1724-11D7-8645000102C1865D

Ahlbrandt, T.S., Huffman, A.C., Fox, J.E., and Pasternack, I., 1979, Depositional framework and reservoir quality studies of selected Nanushuk Group outcrops, North Slope, Alaska, in Ahlbrandt, T.S., ed., Preliminary geologic, petrologic, and paleontologic results of the study of Nanushuk Group rocks, North Slope, Alaska: U.S. Geological Survey Circular 794, p. 14-31. http:// pubs.usgs.gov/circ/1979/0794/report.pdf

Atkinson, C.D., McGowen, J.H., Bloch, Salman, Lundell, L.L., and Trumbly, P.N., 1990, Braidplain and deltaic reservoir, Prudhoe Bay Field, Alaska, in Barwis, J.H., McPherson, J.G., Studlick, J.R.J., and Ginsburg, R.N., eds., Sandstone Petroleum Reservoirs: New York, Springer-Verlag, p. 205-224.

Bartsch-Winkler, Susan, 1979, Textural and mineralogical study of some surface and subsurface sandstones from the Nanushuk Group, western North Slope, Alaska, in Ahlbrandt, T.S., ed., Preliminary geologic, petrologic, and paleontologic results of the study of Nanushuk Group rocks, North Slope, Alaska: U.S. Geological Survey Circular 794, p. 61-76. http://pubs.usgs.gov/ circ/1979/0794/report.pdf

Bartsch-Winkler, Susan, 1985, Petrography of sandstones of the Nanushuk Group from four measured sections, central North Slope, Alaska, in Huffman, A.C., Jr., ed., Geology of the Nanushuk Group and related rocks, North Slope, Alaska: U.S. Geological Survey Bulletin 1614, p. 75-95. http://www.dggs.alaska.gov/pubs/ id/3709

Bartsch-Winkler, Susan, and Huffman, A.C., Jr., 1988, Sandstone petrography of the Nanushuk Group and Torok Formation, in Gryc, George, ed., Geology and exploration of the National Petroleum Reserve in Alaska, 1974 to 1982: U.S. Geological Survey Professional Paper 1399, p. 801-831. http://dggs.alaska.gov/pubs/id/4007

Basu, A., Young, S.W., Suttner, L.J., James, W.C., and Mack, G.H., 1975, Re-evaluation of the use of undulatory extinction and polycrystallinity in detrital quartz for provenance interpretations: Journal of Sedimentary Petrology, v. 45, no. 4, p. 873-882. doi:10.1306/212F6E6F2B24-11D7-8648000102C1865D

Beard, D.C., and Weyl, P.K., 1973, Influence of texture on porosity and permeability of unconsolidated sand: American Association of Petroleum Geologists Bulletin, v. 57, no. 2, p. 349-369. doi:10.1306/819A4272-16C511D7-8645000102C1865D

Blatt, Harvey, 1982, Sedimentary petrology: New York, W.H. Freeman and Company, 514 p.

Blatt, Harvey, Middleton, Gerard, and Murray, Raymond, 1980, Origin of sedimentary rock, 2nd edition: Englewood Cliffs, NJ, Prentice-Hall, Inc., 766 p.

Boggs, Sam, Jr., 2009, Petrology of sedimentary rocks, 2nd edition: New York, Cambridge University Press, 599 p.

Burns, W.M., Hayba, D.O., Rowan, E.L., and Houseknecht, D.W., 2005, Estimating the amount of eroded section in a partially exhumed basin from geophysical well logs-An example from the North Slope: Studies by the U.S. Geological Survey in Alaska, 2005, U.S. Geological Survey Professional Paper 1732-D, 18 p. http://pubs. usgs.gov/pp/pp1732/

Clark, A.C., 2014, Coalbed natural gas exploration, drilling activities, and geologic test results, 2007-2010, Wainwright, Alaska: U.S. Geological Survey Open-File Report 2014-1004, 65 p. doi:10.3133/ofr20141004

Decker, J.E., 1985, Sandstone model analysis procedure: Alaska Division of Geological \& Geophysical Surveys Public Data File 85-3, 38 p. doi:10.14509/1084

Decker, J.E., and Helmold, K.P., 1985, The effect of grain size on detrital modes-A test of the Gazzi-Dickinson point-counting method-Discussion: Journal of Sedimentary Petrology, v. 55, no. 4, p. 618-620.

Decker, P.L., 2010, Brookian sequence stratigraphic framework of the northern Colville foreland basin, central North Slope, Alaska [poster and presentation]: Alaska Department of Natural Resources Spring Technical Review Meeting, Anchorage, April 21-22, 2010: Alaska Division of Geological \& Geophysical Surveys, 30 p., 1 sheet. doi:10.14509/21861

Decker, P.L., and LePain, D.L., 2016 [this volume], Subsurface relationships of Albian-Cenomanian shallow marine to nonmarine topsets of the Nanushuk Formation, northwestern NPRA, northern Alaska, in LePain, D.L., ed., Stratigraphic and reservoir quality studies of continuous core from the Wainwright \#1 coalbed methane test well, Wainwright, Alaska: Alaska Division of Geological \& Geophysical Surveys Report of Investigation 2016-3, 56 p. doi:10.14509/29655

Folk, R.L., 1974, Petrology of sedimentary rocks: Austin, TX, Hemphill Publishing Co., 182 p.

Franks, S.G., and Lee, M.K., 1994, Preliminary report on diagenesis of upper Cook Inlet sandstones: Atlantic Richfield Company report, $46 \mathrm{p}$.

Garrity, C.P., Houseknecht, D.W., Bird, K.J., Potter, C.J., Moore, T.E., Nelson, P.H., and Schenk, C.J., 2005, U.S. 
Geological Survey 2005 oil and gas resource assessment of the central North Slope, Alaska-Play maps and results: U.S. Geological Survey Open-File Report 2005-1182, 25 p. http://pubs.usgs.gov/of/2005/1182/

Gillis, R.J., Decker, P.L., Wartes, M.A., Loveland, A.M., and Hubbard, T.D., 2014, Geologic map of the south-central Sagavanirktok Quadrangle, North Slope, Alaska: Alaska Division of Geological \& Geophysical Surveys Report of Investigation 2014-4, 24 p., 2 sheets, scale 1:63,360. doi:10.14509/29138

Houseknecht, D.W., and Schenk, C.J., 2001, Depositional sequences and facies in the Torok Formation, National Petroleum Reserve-Alaska (NPRA), in Houseknecht, D.W., ed., NPRA core workshop-Petroleum plays and systems in the National Petroleum Reserve-Alaska: Society for Sedimentary Geology (SEPM) Core Workshop Notes, v. 21, p. 179-199. doi:10.2110/cor.01.01.0179

Houseknecht, D.W., Bird, K.J., and Schenk, C.J., 2008, Seismic analysis of clinoform depositional sequences and shelf-margin trajectories in Lower Cretaceous (Albian) strata, Alaska North Slope: Basin Research, v. 21, no. 5, p. 644-654. doi:10.1111/j.1365-2117.2008.00392.x

Howard, J.J., 1992, Influence of authigenic clay minerals on permeability, in Houseknecht, D.W., and Pittman E.D., eds., Origin, diagenesis, and petrophysics of clay minerals in sandstones: Society of Economic Geologists and Paleontologists Special Publication No. 47, p. 257-264. Huffman, A.C., Ahlbrandt, T.S., Pasternack, Ira, Stricker, G.D., and Fox, J.E., 1985, Depositional and sedimentologic factors affecting the reservoir potential of the Cretaceous Nanushuk Group, central North Slope, in Huffman, A.C., ed., Geology of the Nanushuk Group and related rocks, North Slope, Alaska: U.S. Geological Survey Bulletin 1614, p. 61-74. http://dggs.alaska.gov/ pubs/id/4561

Ingersoll, R.V., Bullard, T.F., Ford, R.L., Grimm, J.P., Pickle, J.D. and Sares, S.W., 1984, The effect of grain size on detrital modes-A test of the Gazzi-Dickinson pointcounting method: Journal of Sedimentary Petrology, v. 54, no. 1, p. 103-116. doi:10.1306/212F83B9-2B2411D7-8648000102C1865D

Jahren, J., and Ramm, M., 2000, The porosity-preserving effects of microcrystalline quartz coatings in arenitic sandstones-Examples from the Norwegian continental shelf, in Worden, R.H. and Morad, S., eds., Quartz cementation in sandstones: International Association of Sedimentologists Special Publication, v. 29, p. 271-280. doi:10.1002/9781444304237.ch18

Johnsson, M.J., and Sokol, N.K., 2000, Stratigraphic variation in petrographic composition of Nanushuk Group sandstones at Slope Mountain, North Slope, Alaska, in Kelley, K.D., and Gough, L.P., eds., Geologic studies in Alaska by the U. S. Geological Survey, 1998: U.S. Geological Survey Professional Paper 1615, p. 83-100. http://pubs.usgs.gov/pp/p1615/
LePain, D.L., and Decker, P.L., 2016 [this volume], Lithofacies analysis of the Wainwright \#1 continuous core, western Arctic Slope, Alaska-Transition from lower to upper delta plain environments in the Albian-Cenomanian Nanushuk Formation, in LePain, D.L., ed., Stratigraphic and reservoir quality studies of continuous core from the Wainwright \#1 coalbed methane test well, Wainwright, Alaska: Alaska Division of Geological \& Geophysical Surveys Report of Investigation 2016-3, 56 p. doi:10.14509/29656

LePain, D.L., McCarthy, P.J., and Kirkham, R., 2009, Sedimentology and stratigraphy of the Middle AlbianCenomanian Nanushuk Formation in outcrop, central North Slope, Alaska: Alaska Division of Geological \& Geophysical Surveys Report of Investigation 2009-1, version 2, 76 p. doi:10.14509/19761

Lundegard, P.D., 1992, Sandstone porosity loss-A "big picture" view of the importance of compaction: Journal of Sedimentary Petrology, v. 62, no. 2, p. 250-260.

Molenaar, C.M., 1985, Subsurface correlations and depositional history of the Nanushuk Group and related strata, North Slope, Alaska, in Huffman, A.C., ed., Geology of the Nanushuk Group and related rocks, North Slope, Alaska: U.S. Geological Survey Bulletin 1614, p. 61-74. http://pubs.usgs.gov/pp/1614/pp1614_report.pdf

Mull, C.G., 1995, The geological distribution of chert in the Brooks Range: Alaska Division of Geological \& Geophysical Surveys Public Data File 95-32, 13 p. doi:10.14509/1711

Mull, C.G., Houseknecht, D.W., and Bird, K.J., 2003, Revised Cretaceous and Tertiary stratigraphic nomenclature in the Colville Basin, northern Alaska: U.S. Geological Survey Professional Paper 1673, 59 p. http://dggs. alaska.gov/pubs/id/4052

Neasham, J.W., 1977, The morphology of dispersed clay in sandstone reservoirs and its effect on sandstone shaliness, pore space, and fluid flow properties [presentation SPE 6858]: Society of Petroleum Engineers Annual Technical Conference and Exhibition, Denver, CO, October 9-12, 1977.

Reifenstuhl, R.R., and Loveland, Andrea, 2004, Reservoir characterization study: porosity and permeability of 148 Tertiary to Mississippian age outcrop samples, east-central Brooks Range Foothills and North Slope, Alaska: Alaska Division of Geological \& Geophysical Surveys Preliminary Interpretive Report 2004-5, 21 p. doi: $10.14509 / 3312$

Velleman, P.F., 1998, Learning data analysis with the student version of Data Desk 6.0: Ithaca, New York, Addison-Wesley, $362 \mathrm{p}$. 